\title{
The Economic and Social Roots of Populist Rebellion: Support for Donald Trump in 2016
}

\author{
Thomas Ferguson, Benjamin Page, Jacob Rothschild, \\ Arturo Chang, and Jie Chen*
}

\author{
Working Paper No. 83
}

October 2018

\begin{abstract}
This paper critically analyzes voting patterns in the 2016 U.S. presidential election. Using survey data from the American National Election Survey and aggregate data on Congressional districts, it assesses the roles that economic and social factors played in Donald J. Trump's "Populist" candidacy. It shows the hollowness of claims that economic issues played little or no role in the campaign and that social factors such as race or gender suffice to explain the outcome. While agreeing that racial resentment and sexism were important influences, the paper shows how various economic considerations helped
\end{abstract}

\footnotetext{
* Thomas Ferguson is Professor Emeritus at the University of Massachusetts, Boston, Director of Research at the Institute for New Economic Thinking, and Senior Fellow at Better Markets; Benjamin I. Page is Gordon S. Fulcher Professor of Decision Making at Northwestern University; Jacob Rothschild and Arturo Chang are at Northwestern University; Jie Chen is University Statistician at the University of Massachusetts, Boston. An earlier version of this paper was presented at the annual meeting of the American Political Science Association, August 29-September 2, 2018 in Boston. Page gratefully acknowledges support from the Institute for New Economic Thinking. The authors thank Irene Kwon and Zihang Ruan for valuable research assistance. The paper represents the views of the authors and not any institution with which they are affiliated.
} 
Trump win the Republican primary and then led significant blocs of voters to shift from supporting Democrats or abstaining in 2012 to vote for him. It also presents striking evidence of the importance of political money and Senators' "reverse coattails" in the dramatic final result.

Keywords: political economy, voting, 2016 presidential election, Donald Trump, Populism, political parties, political money, international economic policy, free trade

JEL Classifications: D71, D72, G38, P16, N22, L51 
Donald Trump's election in 2016 as president of the United States can be taken as a striking example of the rise of right-wing populism in many advanced countries of the world, including Europe.

Scholars and others have debated what the roots of that populism are among mass publics. For example, did voters in the United States respond chiefly to social anxieties racism, xenophobia, sexism? Or mainly to economic distress - lost jobs, stagnant wages, home foreclosures, health care crises, student loan debt, and the like?

Some leading analysts have concluded that social anxieties overwhelmingly predominated. They argue that the story is simple: Trump was elected by "deplorables," fueled by racial resentment, sexism, and fear or dislike of immigrants from abroad. Economics, they say, made little or no difference. ${ }^{1}$

We disagree. Social anxieties certainly did play an important part in Trump's victories particularly in the 2016 Republican primaries, where many voters were indeed motivated by resentments related to race, ethnicity, immigration, and gender. Social issues were important in the general election as well. But upon careful examination of several types of data, the real picture looks considerably more complicated.

Economic factors mattered, too, at both stages. Moreover, in the general election - in contrast to the primaries - many leading social factors actually tended to hurt rather than help Trump. Furthermore, the social and economic factors were deeply intertwined with each other - as becomes apparent upon close examination of Americans' spontaneous, open-ended comments about what they "liked" and "disliked" about the parties and candidates. The 
importance of economic factors also comes through clearly when we examine the impact of aggregate (congressional-district-level) contextual data, and when we address the crucial question of why some Americans switched from voting for Obama (or not voting) in 2012, to voting for Trump in 2016.

\section{Theory}

In recent years "populism" has become a catch-all term applied to mass revolts (at the ballot box or in the streets) of disparate sorts, ranging from anti-immigration, anti-austerity, anti-globalization parties and movements in advanced European democracies; to antiestablishment protests against shaky post-Soviet regimes in eastern Europe; and even to popular support for various autocratic movements or regimes including that of Vladimir Putin whose popularity among ordinary Russians partly reflects nationalistic anger at Russia's loss of world stature, and resentment of perceived outside (Western) political and economic encroachments, as well as personal economic and social grievances. ${ }^{2}$ Not long ago the chief locus for talk about "populism" was Latin America, where much popular discontent was aimed at IMF-imposed austerity and at perceived pressures from economic globalization in general and from the United States in particular. ${ }^{3}$

Some observers have tended to lump all these populisms together, seeing them as exploiters of social divisions and threats to liberal democracy, civic protections, international commerce, respect for truth - and indeed to democracy itself. ${ }^{4}$ A more nuanced analysis, however, indicates that they differ from each other in important ways; that the grievances 
fueling them are often quite real; and that some populist movements have been quite democratic in both aims and methods.

To be sure, disparate forms of "populism" have at least one thing in common: widespread popular anger and resentment against powerful elites, foreign or domestic. Populist subjects are generally bound together in anti-establishment "movement" activity that organizes resistance to perceived structural threats to their daily lives. But there have been important differences in the sources of anger and resentment, in the beliefs and actions they have inspired, in the political aims they have fueled, and in their organizational and governmental results. If the term "populism" is to be analytically useful, it is essential to make some distinctions.

Political theorists' distinctions between "organizational" and "ideational" concepts of populism are not central for our present purposes. ${ }^{5}$ But one crucial distinction follows from the work of Jason Frank, Lawrence Goodwyn, and Michael Schwartz. The left-oriented populism of the nineteenth century U.S. Farmers Alliance and Peoples Party was quite different from the right-wing populisms of today. ${ }^{6}$

Nineteenth century American populists were by no means authoritarian; they were deeply committed to democracy. They pioneered new forms of community cooperation (including local credit facilities for farmers) and worked for democratic political reforms like the direct election of U.S. Senators and women's suffrage, some of which were subsequently enacted during the Progressive period. These left populists objected to exploitative banks and railroads and to extremely unequal wealth. They emphasized economic reforms, self-education, and cooperative action projects. They did not exploit social divisions. At a time when the South 
was dominated by white racists, southern populists generally embraced equality for African Americans and actively pursued interracial cooperation. Women occupied some top leadership positions. ${ }^{7}$ And the People's Party worked hard (though unsuccessfully) to form a nationwide coalition of farmers and workers of all races, ethnicities, and genders. This egalitarian and collectivized approach to extra-institutional politics formed the "movement culture" of nineteenth century populism.

Arguably, today's Bernie-Sanders-style populism has much in common with its nineteenth century predecessors.

Be that as it may, we consider it essential to distinguish right-wing from left--wing populism. Left-wing populism is generally democratic in composition (cutting across social divisions) and democratic in ideology (seeking to work through, and improve, democratic institutions.) Right-wing populism, on the other hand - including the relatively mild Trump version - tends to embrace strong, authoritarian leaders; to exploit social divisions; to blame social scapegoats (immigrants, minorities, women) for suffering and distress; and to pursue policies that do little or nothing to deal with economic grievances that may fuel the discontents that motivate supporters. This can amount to a politics of distraction, even demagoguery.

Our focus here is on what leads to public support for right-wing populism, as exemplified by Donald Trump in his campaign appeals of 2016 (which, of course, were not identical with the mostly establishment-Republican program he later pursued as president). In our broader project we plan to compare the roots of support for the left-wing populism of Bernie Sanders. But here we focus on Trump. 
Our theoretical understanding of right-wing populism begins with the observation that many different sorts of discontent may fuel it. A major example is that of Hitler's Nazi movement, which had roots in nationalist resentments after Germany's defeat in World War I. Those resentments were consciously channeled by right-wing politicians into blaming Social Democrats, liberals, and Jews for a "stab in the back." The Nazis gained further traction from the severe economic distress that beset Weimar Germany in the 1920s and early 1930s, which again was channeled into resentment of scapegoats, particularly Jews - a target made more vulnerable by previous German anti-Semitism. ${ }^{8}$

Other cases of right-wing populism have exploited quite different types of popular resentment and discontent. A key driver of contemporary right-wing populism in Europe and the United States, of course, is anger about high levels of immigration - the economic threat posed by an influx of competing low-wage workers; social anxieties about foreigners who look, talk, and act differently from the natives; and worry about demands that immigrants put on public services that have often been starved by years of fiscal austerity. Immigration has been particularly troubling in countries like Italy and the United States with long coastlines or borders that can be breached relatively easily,

Along with immigration, a major force behind contemporary right-wing populism is decades of downward pressures on jobs and wages resulting from economic globalization particularly from international trade with - and investment of mobile capital in - low-wage countries like China, India, and the Asian "tigers."9

We believe that an important mechanism for translating such discontents into rightwing populism is what Hannah Arendt has (with something other than a rational public in mind) 
strikingly termed an "alliance between the mob and capital." The central idea is that wealthy elites deliberately exploit mass economic discontent and channel it away from economic reforms (which would be costly to the elites) and toward social resentments and social scapegoats. ${ }^{10}$ This defuses political threats to the elites and indeed can help them gain or maintain political power to defend their privileges.

How, in theoretical terms, might such an alliance work? We suggest that a successful political strategy of this sort requires, in addition to a reservoir of popular discontent (often primarily economic in origin), a plausible story about social scapegoats that can be made to resonate with important parts of the public. Plausibility, in turn, is likely to depend upon preexisting beliefs and attitudes, and (to some degree) upon a modicum of connection with empirical reality.

Thus the German "stab in the back" story gained credence from pre-existing German anti-Semitism, and by deliberate efforts to single out prominent Jewish statesmen and financiers who supported the Weimar government or whose enterprises got into various forms of trouble. Similarly, Trumpian right-wing populism in the United States has drawn upon longstanding American racism along with a long-running campaign by many Republicans to link public assistance to African-Americans, even though most the programs in fact benefit larger numbers of poorly-educated whites. ${ }^{11}$

Again, the fanning of anti-immigrant sentiments in the U.S. and Europe has been facilitated by long-standing suspicions of foreigners among natives of almost every countryunease with people who look different, speak different languages, and behave in different ways. Such attitudes have undoubtedly been exacerbated by the facts of extensive immigration 
(much more than in previous decades) and economic competition in a disappointing job market. Further, the unhappy fallout from economic globalization - stagnant wages, job losses, factory closings and the like - can more or less plausibly be blamed on wily or unscrupulous foreigners, Mexican or Chinese.

To this sketch of a theory of right-wing populism we would add one more element concerning the dynamics by which scapegoating stories emerge over time. In many cases it is not initially obvious what sort of story will work best for inflaming and channeling popular discontents. In such cases, elites may experiment with alternative stories, try them out and see what works. Sometimes a scapegoat story may be seen almost at once to be a sure winner, as when right-wing German leaders such as Hindenberg and Ludendorf quickly saw that Jews and liberals would be excellent scapegoats for Germany's lost war. ${ }^{12}$ More often, alternative scapegoat stories need to be tried out, selected, combined, and honed over time, until a highly effective right-wing populist appeal is worked out. This process can resemble something like Karl Popper's cycles of "conjecture and refutation," with the difference that this is not science, but a battle for popular opinion in which facts are only one ingredient of persuasiveness. ${ }^{13}$

In the U.S. case, for example, over the course of several decades during which both Republican and Democratic office holders were mostly ignoring distress and discontent resulting from cheap imports, flight of capital abroad, and high levels of immigration, a few political entrepreneurs - notably including Steve Bannon and, as we will see below, Donald Trump - developed scapegoat stories. Trump tried out some of them in his early public flirtations with the idea of running for president. Then, for the 2015-16 campaign, he perfected a message that included denigration of Mexican and Muslim immigrants, 
demonization of Chinese exports of cheap goods, and subtle evocations of misogyny and racism aimed at women and African Americans. ${ }^{14}$

\section{Trump's Message to Voters}

In 2016 millions of Americans were angry at establishment politicians of both major parties. For decades, cheap imports and automation had had nasty side effects - cutting our manufacturing work force, closing U.S. factories, and, in many cases, pressuring wages downward - without much help being offered to those afflicted. A full scale "dual economy" had come into being, in which vast numbers of Americans were working at low wages, with little prospect of ever joining the middle class. ${ }^{15}$ But free international trade and technological progress had been enthusiastically embraced and encouraged by the leaders of both parties.

More recently, the Great Recession of 2008-9 had hit many Americans with further new job losses, bankruptcies, and loss of their homes to foreclosure. Recovery from the Great Recession was slow and uneven, with the wealthy leaping ahead while most Americans struggled to regain their former positions. Once again, establishment politicians of both parties seemed to have little interest in helping ordinary citizens, but they had quickly bailed out big banks with cheap loans and subsidies. ${ }^{16}$ Little wonder that by early 2016 most Americans viewed both political parties negatively. Some three quarters of the public said the country was on the "wrong track." 17

Economic travails may well have been the deepest and most fundamental sources of this discontent, but certain social stresses contributed as well. High levels of immigration (especially illegal or undocumented immigration from Mexico) fed into social as well as economic anxieties. Women's gains in independence and control over their lives had 
disquieted traditionalists, especially among older white males. Many whites also saw the relative progress of African Americans as unfairly coming at their own expense. Terrorism abroad had stoked fears that Americans might be attacked at home. ${ }^{18}$ Lots of fuel was available for lighting fires of right-wing populism.

In order to understand what about Donald Trump's particular brand of populism attracted many American voters (and repelled many others), it is important to be clear about exactly what sorts of messages he delivered. Most aspects of Trump's messaging fit well with our general conception of right-wing populism. He relied heavily on scapegoating various incarnations of "the other." But Trump's rhetoric also had certain distinctive features, some of them unique to the twenty-first century United States, and some of them involving carefully calculated nods to the most popular elements of left-wing populism,

One central aspect of Trump's message neatly fit the right-wing populist playbook: he loudly and insistently pointed, as causes of Americans' economic and social distresses, at a series of human scapegoats. Besides "donors," "insiders," and "powerful politicians," these included various foreigners: Muslim immigrants or refugees - perhaps even Muslim Americans - whom he portrayed as potential terrorists; Mexican immigrants, characterized as criminals, welfare free-loaders, job-stealers, and culture-disruptors; and Chinese workers and exporters, scorned as sources of cheap imports that undermined American jobs and wages. ${ }^{19}$

In a distinctively American variation on this theme, Trump also carefully and subtly drew upon centuries of America's troubled history with race to hint at scapegoating and demonizing African Americans. He was usually careful to avoid overtly racist rhetoric, which would have been socially unacceptable. Instead, he indirectly evoked whites' racial anxieties by making 
insulting remarks about particular African American individuals or groups, by stoking the whites' resentments against the real or imagined effects of affirmative action, and especially by attacking our first black president, Barack Obama. ${ }^{20}$ Trump's approach to women was similarly subtle. He avoided any wholesale attacks on women per se (who, after all, constituted a majority of the electorate.) But he tossed demeaning insults at particular women who were easy targets.

As Obama emerged as a major political figure and then was elected president, Trump promoted a false but (to some Americans) plausible and alarming message that cleverly evoked both xenophobia and racism in one simple trope: the "birther" claim that Obama was not a real American at all. He was a foreigner, a Muslim born in Indonesia or perhaps even Kenya, son of a Kenyan father. He was imbued with Kenyan anti-colonial, anti-Western values. This lie gained plausibility from its wisps of truth: Obama was a Christian, not a Muslim, and had been born in the United States (Hawaii); but he did have a Kenyan father, he had spent some of his childhood in Indonesia, and he had said some friendly things about Islam. ${ }^{21}$

Trump and other "birthers" got substantial traction with this message through certain non-mainstream media and convinced a fair number of Americans who were susceptible to racist and xenophobic appeals. ${ }^{22}$ Obama's initial reluctance to find and release his original birth certificate did not help. But when the disgusted president finally yielded and dug up the birth certificate, the "birther" nonsense was deflated, among most, but not all its adherents. ${ }^{23}$ In similar trial and error fashion, Trump moved to develop other scapegoating narratives as he publicly flirted with a run for the presidency in $2012 .{ }^{24}$ By June 15,2015 , when Trump officially announced his presidential candidacy from glitzy Trump Tower, he was well armed and 
ready to go. He had carefully crafted a message that was well designed to explode establishment Republicans' control of their party, winning Trump a major-party nomination and a shot at the presidency itself.

It is instructive to look back at Trump's announcement speech, which includes most of the themes of his later campaign. He opened by charging that in international trade, China and Japan "kill us," "beat us all the time." He asserted that Mexico is "killing us economically," and then shifted to a broadside against Mexican immigrants, declaring (with his trademark disdain for evidence): "They're bringing drugs. They're bringing crime. They're rapists." "It's coming from all over South and Latin America" and "probably the Middle East...we don't know....Islamic terrorism is eating up large portions of the Middle East." Trump went on to blast ISIS and to lament the costs of the Iraq war, after which (he said) ISIS and Iran got "the oil." This concise catalogue of foreign threats via trade and immigration and foreign policy failures was well designed to feed xenophobia. ${ }^{25}$

Trump's scapegoating foreigners was not as crude as is sometimes remembered, however. He disclaimed any animus against foreign people generally: "I like China" (their "U.S. headquarters" was in Trump Tower), and their leaders were smart. "I love the Saudis," despite their failure to pay for U.S. military protection. Even about Mexican immigrants, he noted that "some, I assume, are good people."

Trump's explicit targets, instead, were chiefly American elites, including "donors," "lobbyists," the "powerful," and the corrupt politicians they controlled. (Trump claimed to be a self-funder, free from such influence) Above all he blamed the "stupid," "clueless" U.S. negotiators who, he said, had repeatedly sold out the United States with terrible trade deals, 
and who had sent brand-new U.S. equipment to Iraq and Yemen only to have it abandoned on the battlefield.

More quietly, Trump shot a few arrows at his leading rivals for the Republican nomination, such as unnamed "other people" who "want to cut the hell out" of Social Security. He noted that Jeb Bush and Marco Rubio were "unable to answer" the simple question of whether the Iraq War was a good thing or a bad thing. (Trump himself falsely claimed to have opposed the war from the start.) Bush, he said, was "weak on immigration" and favored the education Common Core, which was despised on the right.

Also, in the fashion of more conventional politicians, Trump frequently linked his negative attacks to more or less plausible, though vague, policy proposals. Toward the end of his announcement speech he ran through a litany of proposals: to inexpensively build a "great wall" on the border with Mexico and have Mexico pay for it (this evolved into a major campaign theme); to be "tougher on ISIS"; to appoint a Patton-like general and make the military "really work"; to "stop Iran from getting nuclear weapons"; to "immediately terminate" "Obama's illegal executive order on immigration"; to "fully support and back up the Second Amendment"; to end the "disaster" of the educational Common Core; to "reduce our \$18 trillion debt"; to "strengthen our military"; and to "take care of our vets."

Near the close of his announcement speech, Trump even spoke in favor of several highly popular government programs that are more often associated with left populism. He promised to "save Medicare, Medicaid, and Social Security without cuts." At some length, evoking his experience as a builder, Trump promised to "[r]ebuild the country's infrastructure": bridges, roadways, and airports that he said were far inferior to those of China or Qatar. He would do 
so "on time, on budget, way below cost," at one-third the cost. Although these promises did not fare well after Trump took office, they were repeated frequently throughout the campaign and may well have helped attract voters.

So Trump's invitation to scapegoat "the other" for America's problems did not completely lack subtlety, and did not lack connections with actual problems and potential policy solutions. Particularly subtle was his treatment of women and African Americans. No hint of misogyny or racism appeared in his announcement speech. His later efforts to channel white males' anger in those directions were carefully pitched "dog whistles" that would arouse target audiences but not offend the broad public.

In the Republican primary elections that began in early 2016, a phalanx of establishment Republicans - some sixteen of them, several with well-polished credentials and appealing personas -- emerged to battle Trump. The early front-runners were Jeb Bush (son of former President George H.W. Bush) and Marco Rubio (senator from Florida). They were joined by Scott Walker, the anti-union Wisconsin governor beloved by billionaires; Ted Cruz, a preachers' son backed by many Christian social conservatives, and many more, some serious and some not. These included surgeon (and African American) Ben Carson; former Hewlett Packard executive Carly Fiorina; and several retreads from previous campaigns, such as Texas Governor Rick Perry, a favorite of the oil industry; former House Speaker Newt Gingrich; faintly populistic former Arkansas governor Mike Huckabee, and New Jersey Governor Chris Christie. ${ }^{26}$

Trump beat them all. All were vulnerable to attack as establishment facilitators of the "disastrous" free trade deals and "open" immigration policies that Trump was excoriating. Rubio (of Latino ancestry) and Bush (a proud Spanish speaker with an Hispanic wife), were 
particularly vulnerable among Republican primary voters for their past backing of immigration reforms that would have included some form of the dreaded "amnesty" and a path to citizenship. All of Trump's opponents had enthusiastically backed free international trade, though a few were experimenting with various qualifications. ${ }^{27}$ Several had quietly supported the Paul Ryan plan to, as Trump put it, "cut the hell out of Social Security." After years of promoting major policies that were anathema to the Republican base (let alone to the broader American public), all these GOP candidates - in fact all establishment Republicans - were standing on shaky ground. Trump shook that ground.

In addition, Trump displayed a devilish talent for devising and firing off personalized insults at his opponents: "low-energy" Bush (who did indeed seem rather relaxed): "little Marco" Rubio (who was indeed short in stature); and "lying Ted" Cruz, who oozed sincerity but had been known to prevaricate. One by one, Trump defeated them in the primaries and forced them to withdraw. Toward the end only Ted Cruz was left standing against Trump. Cruz had accumulated quite a few delegates in caucus states (thanks to his intense backing by Evangelical activists and a handful of major donors), and he won a few primaries as well. But well before convention time Trump buried him. ${ }^{28}$

During the primary season Trump perfected the technique of arousing and exploiting -while not overtly expressing - xenophobia, misogyny and racism, by picking on individuals rather than groups. He ridiculed the physical appearance of several women media personalities. He mocked the Muslim parents of an American hero who had died in the Iraq war (perhaps not the best choice of target.) He hinted that the Latino-heritage judge (Curiel) who was presiding over a lawsuit against Trump could not be possibly be unbiased. ${ }^{29}$ 
Once Trump won the Republican nomination he turned his full fire onto Hillary Clinton and the Democrats. He pilloried "crooked Hillary" (a telling phrase that he had launched just before the New York Republican primary), which provoked rally chants of "lock her up." As Jonathan Allen and Amie Parnes observe in their book ("Shattered") about Clinton's doomed campaign, she was a near-perfect target at which to direct resentments of out-of-touch elites, rich donors, and pro-globalizing politicians who pandered to them. It did not help that Bernie Sanders repeatedly ridiculed Clinton's six-figure speaking fees and her ties to Wall Street, though it is hard to imagine that Trump would not have thought of that on his own. ${ }^{30}$

Trump also pursued the "strong leader" theme. He repeatedly spoke of the need for "competence," touting his supposed self-made economic success and wizardry at making deals. In his July 21 speech accepting the GOP nomination, Trump focused on law and order, deploring "terror" and "violence" that he said were afflicting the United States. He moved seamlessly from violence against the police, to instances of radical Islamic terrorism, to crimes committed by illegal immigrants from Mexico. ${ }^{31}$

Trump's mid-August 2016 speech in Charlotte, North Carolina, was unusual in its moderate tone and broad appeals; the Washington Post, no friend of Trump, anointed it as his "best speech" to date. (Trump declared that we are "one nation"; he went on at some length about the need to help African Americans; and he spoke warmly in favor of opportunity and equal treatment.) But the Charlotte speech provides a handy preview and catalog of nearly all of Trump's general-election themes. ${ }^{32}$

In Charlotte Trump alluded to his plans to "bring jobs back to our country," to "defeat Radical Islamic Terrorism," to "restore law and order," and (in a nod to the left) to "provide 
opportunities for all of our people." He bemoaned factory workers' losses of jobs and the denial of medical care to veterans. He sympathized with families near the border who had "no security at all." He lamented "failing schools"; "terrible trade deals"; "crumbling" infrastructure in our inner cities. Trump promised "a new future of honesty, justice and opportunity."

He attacked "arrogant leaders," calling Hillary Clinton "one of the greatest liars of all time": "she never tells the truth." She had lied about her "illegal" email server, and had turned the State Department into a "pay-for-play operation where favors [were] sold to the highest bidder." She had lied to the families who had lost loved ones at Benghazi. She had put Iran "on the path to nuclear weapons." She had not apologized for Iraq, for Syria, for Libya, or for "unleashing ISIS across the world." Thus he linked his opponents directly to popular resentment of what were widely seen as failed foreign policy decisions.

Trump once again aimed heavy fire at trade agreements, noting North Carolina's loss of manufacturing jobs since NAFTA had gone into effect and China had joined the WTO. He then pivoted to "[o]ur open border," which he claimed "has allowed drugs and crime and gangs to pour into our communities." "[S]o much preventable death" had been caused by open borders and by Hillary-supported Sanctuary Cities, he charged.

Trump claimed to be "a champion of the people," who would never put personal profit or special interests before the national interest. He promised to be the voice of ordinary citizens against "hedge fund managers, the financial lobbyists, the Wall Street investors": "[i]t's the powerful protecting the powerful."

In the last third of his Charlotte speech Trump turned to a litany of policy proposals, refined from - but closely resembling - those listed in his announcement of candidacy. He 
would "end the era of nation building" and instead focus on "destroying, destroying, destroying" ISIS and radical Islamic terrorism. He promised to "use military, cyber, and financial warfare," and work with any available partner, to defeat terrorism. Trump promised to "temporarily suspend immigration" from any place without adequate screening (a softer variant of his "Muslim ban"), and to engage in "extreme vetting." He opposed Clinton's support for admitting more ("550 percent" more) Syrian refugees.

Continuing with policy proposals, Trump promised to "add more police" and more investigators, and to appoint "the best judges and prosecutors in the world." He would pursue strong enforcement of federal laws against gangs, cartels, and the "criminal syndicates terrorizing our people." On trade, he vowed to "renegotiate NAFTA to make it better" (or withdraw), and to "withdraw from the Transpacific Partnership, another disaster." He would "stand up to China on our terrible trade agreements" that had "stripped this country of its jobs and its wealth." On taxes, he promised to "massively cut tax rates for workers and small business. He would "get rid of regulations" that send jobs overseas; "give students choice and allow charter schools to thrive"; "end tenure" that rewards bad teachers; "work closely with African American parents and students" on education; and he would "repeal and replace the disaster called ObamaCare" (asserting that premiums were about to jump by double digits again that week.) Trump went on to promise to "restore honor" to government, protecting classified information and forbidding senior officials from trading favors for cash by collecting lavish speaking fees through their spouses (a dig at Hillary and Bill Clinton.) 
After a nod to opportunity and equal treatment of every American, Trump closed with his signature promise to "make America "strong again," "proud again," "safe again," "great again."

Not all of this potpourri can be said to reflect right-wing populism. Some was orthodox Republican fare, and some leaned left. Nor did Trump's Charlotte speech include the most barbed and inflammatory stump-speech remarks that regularly roused his supporters at rallies. Still, the Charlotte speech did rather faithfully display the whole of Trump's campaign stands, which are important for understanding how Americans reacted to him. And it illuminates Trump's particular variant of right-wing populism.

The next question is: how did voters react?

\section{Trump's Primary Victories}

The picture of Trump's election as heavily driven by social anxieties receives some, though far from overwhelming, support in our analysis of Trump's remarkable romp through the GOP primaries to win the Republican presidential nomination.

There can be little doubt that Trump's success reflected a mass, populist-style revolt against the Republican establishment, which for years had mostly ignored both the social anxieties and the economic distress associated with immigration and free international trade.

Only Trump campaigned against them. ${ }^{33}$

Only Trump effectively bemoaned Americans' job losses and promised revival. ${ }^{34}$ Only Trump made repeated nods toward left-populist programs and the excessive power of wealth. 
These contrasts between Trump's message and the messages of his Republican opponents suggest what sorts of factors might be expected to have influenced voters in the GOP primaries. And indeed, regression analyses of the imperfect ANES data on primary voting confirm that these factors did in fact animate voters' choices. ${ }^{35}$

We carried out a rather extensive exploration of relationships between primary voting and the many ANES variables that one might expect to capture Trump's unique appeal versus all other Republican candidates. We analyzed survey questions related to immigration, free trade, racism, sexism, xenophobia, jobs, incomes, health care, firearms, foreign policy, and the New-Deal-type social welfare policies that Trump promised to protect.

The regression models displayed in the first two columns of Table 1 represents the best we have so far been able to specify: "best" in the sense of accounting for a non-negligible amount of variance, though of course not nearly as much as when accounting for choices between the two major parties (where a host of partisan-related attitudes become relevant). The coefficients are highly significant. We have carefully guarded against multicollinearity and estimated both logistic regressions and random intercept models. The latter take advantage of our congressional district data to attempt to control for differences across congressional districts. ${ }^{36}$ The different techniques produce very similar results.

(Table 1 about here)

From the start of our analyses it was evident that the ANES question about support or opposition to building a Wall against Mexico was strongly related to Trump voting in the primaries - and indeed in the general election as well. The first two columns of Table 1 show this: the coefficient for the Wall variable was quite substantial and highly significant at the .001 
level. Similarly, the issue of Muslim (and potentially terrorist) immigrants played a big part in primary voting. Attitudes for or against allowing Syrian refugees into the country had a large and highly significant coefficient.

Electorates in Republican primaries are very different from the voters who decide general elections. They practically constitute an "alternative universe" that is older, white, richer, and far more conservative in ideology. Among socially very conservative Republican primary voters, concerns about Muslim and Mexican immigrants clearly helped Trump. Substantial majorities of Republican primary voters - though not Americans as a whole declared they favored the Wall and opposed Syrian refugees (see Table 2).

Table 2 about Here

Notably absent from the first two columns of Table 1, however, are two factors that are sometimes thought of as crucial to Trump's appeal: racial resentment and sexism. This is less surprising than it may seem. Tables 3 and 4 display mean responses, for the election years 2008,2012 , and 2016 , on two widely used scales for assessing voters' positions in regard to race and sexism. The first is the "racial resentment" scale developed by Donald Kinder and colleagues; the second is a scale with a somewhat lower alpha that assesses voters' views on a series of questions about their views on women's roles in society. ${ }^{37}$ We have studied the vast literature on measuring and assessing racism in surveys. We took pains to see if these indices somehow failed to catch important aspects of the phenomena they hope to measure. But our analysis convinced us that they are reasonably good instruments. They clearly, for example, distinguish between Clinton and Trump supporters.

(Tables $3 \& 4$ about here) 
In Tables 3 and 4, comparison of average scale scores across three ANES election-year surveys shows an intelligible and rather obvious evolution. Between 2008 and 2016, average scores did not change much (they actually dropped a bit in 2016.) But high scorers on both scales tended to realign into the Republican Party. This does not at all imply that the whole party is racist and sexist, but it does mean that those who held such attitudes tended to have moved over to the GOP by 2016.

Our research has convinced us that several of our colleagues, especially John Sides, Michael Tesler, and Lynn Vavreck, are correct in their assessment that many Republican leaders quite deliberately attempted to racialize opposition to Obama, especially in regard to health care. (See also Peter Temin's discussion of "racecraft" in his book on the American dual economy.) $)^{38}$ One implication of this for Republican primaries is that efforts to disentangle the effects of racial resentment and sexism quickly lead to hopeless multicollinearity. (In the broader context of a general election, the problem dissipates.) Trump's racist and sexist language - which proved to be important in November - was usually rather guarded. His policy stands related to race and gender did not markedly distinguish him from the other Republican candidates in the primaries. Nearly all of were on record opposing policies that were important to African Americans, including government help with health care. Nearly all held traditional views of women's roles in marriage, families, and employment. In this restricted field, Trump did not stand out. For the same reason, questions about whether America was on the "right track," needed a "strong leader," or the demographic category of "white" don't help to distinguish Republican primary voters, but tell heavily as soon as the universe is widened, as in columns 3 and 4 of Table 1, to all primary voters, including Democrats. 
Our statistical analyses also lead to a first important qualification to the "social anxieties above all" view of the contest for the GOP nomination: several economic factors played big parts in primary voting. The high-impact "Wall" issue had an economic dimension. Consistently with Trump's campaign stands, support for limiting imports was also a substantial factor in Trump voting. So, perhaps surprisingly, were two attitudes usually associated with left-wing (Bernie-Sanders-style) rather than right-wing populism: advocacy of government action to reduce economic inequality, and the sentiment that "politicians care only about the rich." These genuinely populist positions, along with Trump's refusal to attack Social Security, marked Trump off from the rest of the Republican field (see Table 1). ${ }^{39}$

All in all, Trump's appeal to the Republican base was quite different from the appeal of the orthodox establishment Republican candidates. This provides one useful window on the roots of populism. Indeed, it can be argued that Trump's performance in the primaries is particularly relevant to our question concerning the economic vs. social roots of right-wing populism. The primaries set populist Trump against a number of definitely non-populist Republican candidates, while avoiding any confusion raised by a two-party general election contest.

Still, we must remember that this analysis is confined to a small and unusual population: the rather small subset of relatively active and intense Republicans (and a few independents) who turned out to vote in the 2016 Republican primaries.

What about voting in the general election, where nearly the entire population of U.S. citizens was potentially eligible to vote? 


\section{Trump's General Election Victory}

The November contest was very different. It involved a much broader electorate; an intensely partisan battle between Republican and Democratic nominees; and, of course, contrasts between Trump and a particular Democratic nominee, Hillary Clinton, with all her distinctive strengths (extensive knowledge and experience; close ties with African Americans, professional women, and many other pro- Democratic subgroups of the population) and her distinctive weaknesses (concerns about her honesty and integrity, her ties to Wall Street, and her general unpopularity as a person - rivaling Trump's own.) This contest between two unpopular candidates with opposite partisan affiliations and many distinctive personal characteristics, is certainly not the ideal laboratory for assessing the roots of populism. Still, we can learn something from it.

Following much the same procedure as in our analysis of the primaries, we explored a host of plausibly relevant independent variables, from attitudes concerning race (particularly the racial resentment scale) and attitudes toward women (the modern sexism scale, and feelings about the Access Hollywood audiotape of Trump's boasting about his sexual aggressiveness toward women); to attitudes toward immigration from Mexico or Muslim countries; to policy preferences concerning jobs and incomes programs, Social Security, the Affordable Care Act, and other social welfare issues; to assessments of whether the economy or the respondent's personal finances had improved or worsened; to general judgments on whether the country as a whole was on the "right track" or the "wrong track."

We analyzed these and other theoretically relevant variables in a number of exploratory regressions, in order to assess which variables best measured the relevant concepts and to get 
an idea of which concepts might have the biggest impacts on voting choices. ${ }^{40}$ The results of three particularly interesting "final" regressions are given in Table 5.

(Table 5 About Here)

As the first column of Table 5 indicates, in November two major types of social attitudes - racial resentment and modern sexism - had large and highly significant $(p<.01)$ effects on voting choices between Trump and Clinton. This is consistent with the big party-related gap in racial resentment, together with Trump's continuing - if sporadic - language denigrating particular African Americans. And it fits with the contrast between Trump - with his fairly frequent sexist language and the release of the Access Hollywood audiotape - and Clinton, an outspoken feminist and the first woman to have a serious shot at the U.S. presidency. ${ }^{41}$ The importance of the "white" (as vs. black or Latino) variable underscores the likely role of racial attitudes in 2016. It may also reflect certain other attitudes not well captured by the measures included in the equation - perhaps conservative white Christians' attitudes about such social issues as abortion, and probably economic as well as social tensions concerning immigration.

The importance of racial resentment and sexism is broadly consistent with other scholars' analyses of ANES and other data, notably including Sides, Tesler and Vavrek. ${ }^{42}$

We must note, however, that - possibly because we were looking harder than others for economic as well as social effects and therefore explored a very wide range of variables certain economic factors also came through as important determinants of voting in the 2016 general election. The question about whether America is on the "Right Track" can be interpreted as partially non-economic, but negative, "wrong track" assessments were probably 
driven in good part by economic anxieties. Beyond that, voters who favored limiting imports were markedly more inclined to vote for Trump than voters who opposed such limits.

Opposition to the Affordable Care Act also appeared to yield Trump votes. Attitudes about the ACA, however - despite its large coefficient and very high estimated significance level - contributed to an unacceptably high level of multicollinearity: a Condition Index of 16.3. Experiments with this variable in a variety of contexts convince us that Michael Tesler's analysis is correct: the many Republican attacks on "Obamacare" succeeded in linking the ACA to racial anxieties. ${ }^{43}$ When we dropped the ACA item from this regression the multicollinearity problem vanished and nothing else changed much. ${ }^{44}$

In the second column of Table 5 we respond to adherents of the view that "party is everything" by adding to the regression model respondents' positions on the seven-point party identification scale as a control variable. We do not generally favor "controls" of this type in attitudinal regressions, because if party is either a cause or a consequence (or both a cause and a consequence) of the other attitudes, some estimated coefficients will tend to be biased. ${ }^{45} \mathrm{In}$ this case, however, the ambiguous role of party identification need not be addressed. Adding a party control has little effect. The estimated coefficients for some clearly party-related factors ("right track," racial resentment, modern sexism, and especially white race of the respondent) seem to drop a bit, but not much in relation to their standard errors. All those coefficients remain large and highly significant. When demographic factors are added too, the substantive results continue to hold. (See the third column of Table 5.)

The role of some economic as well as social factors in 2016 seems well established by the analyses so far. We can further confirm the importance of economic matters in voters' 
thinking by examining what voters actually said, in their own words, in response to open-ended questions about the parties and candidates. This will also suggest a further point: that the neat separation between social and economic is somewhat artificial. The two were actually intertwined in many voters' minds.

\section{In Americans' Own Words}

When 'closed-ended" questions are carefully designed - as they generally are in the ANES - they can be tremendously helpful for data analysis. Yet they suffer from a serious limitation. Even the best-designed questions tend to impose the designers' categories and intellectual frameworks upon respondents.

We believe that election analysts need to take to heart the lesson of work by George Rudé, E.P. Thompson, and many recent historians of feminism, race, and ethnicity: that "history from below" typically looks very different from distillations of specialist or elite opinion. Especially in 2016, with its incendiary invocations of cultural wars, fake news, and global elites, we need to avoid the unhappy fate of Tennyson's Lady of Shalott, who could only perceive the world through her own mirror. It is worth making a special effort to understand what Americans were thinking and saying in their own terms.

Fortunately, from its earliest years the ANES has included a set of "open-ended" questions. Eight separate questions allow respondents to explain in their own words what they like, and then what they dislike, about the Republican and Democratic presidential candidates and about the Republican and Democratic parties. ${ }^{46}$ 
Several scholars, starting with Donald Stokes, have made good use of these open-ended questions, usually by regrouping the detailed codes provided by SRC Michigan into broader categories of theoretical interest. These scholars have made persuasive arguments that most voters are both sufficiently articulate and interested in politics that they can provide substantively useful answers. The responses give a good sense of salient issues on the voter's minds, and tap into a diversity of attitudes. ${ }^{47}$

Critics raise one good point, however: open-ended responses are difficult to summarize, analyze, and understand. They display the full richness of everyday speech. Respondents' own writings (in online responses) as well as interviewers' transcriptions of their oral comments leave in place many misspellings, sentence fragments, and ellipses. Proper names are often mangled, so that even obvious references are easy to miss - particularly by automated content analyses - in the maelstrom of comments. In the 2016 data, for example, references abound to "Begazi" [Benghazi] or "foren" [foreign]. Allusions to international trade and globalization are relatively abundant, but few employ the precise language of economic theory. These features of the interviews make even the stock-in-trade of contemporary textual analysis, simple word counts, treacherous.

The problems go deeper than that. It is often extremely difficult to discern the meaning of comments or even the specific topics they address. In recent years scholars have come to realize that the very detailed SRC coding schemes have been quite unreliable. Different coders often assign the same response to different categories. After exhaustive study, a special task force commissioned by ANES recommended a very different, far more concise coding scheme. ${ }^{48}$ But this has not been put into practice. (We suspect that it may be thought to be too general to 
be of much interest.) Instead, ANES simply stopped coding the open-ended responses and left scholar-users to fend for themselves.

Given this background, we have approached the open-ended data with trepidation and care. Our starting point was established by the ANES task force, which (on its way toward devising a substantive coding scheme) pointed out that an essential first step is to "chunk" all responses into the smallest meaningful evaluative elements. They were able to accomplish this task with high reliability. ${ }^{49} \mathrm{We}$ assembled a group of research assistants to do this same sort of "chunking" with the 2016 data, and took that occasion to correct spelling errors as well.

We have also designed a substantive coding scheme, based on the simplified 38category scheme devised by the ANES task force. (We modified their scheme only slightly, to take better account of references to group identities, forms of economic regulation, and issues like environmental policy.)

Substantive coding is even more labor-intensive and time-consuming than "chunking." So we are not yet able to offer full content analyses of the open-ended responses. What we can do, however, is to report some striking results from counts of some particularly clear cut concepts and terms.

These findings drive a stake through the heart of the argument that in answering these questions respondents just talk off the top of their heads. The concerns they expressed were so widely shared and of such obvious relevance that they plainly speak to matters that the voters cared about.

First, some elementary facts about voter perceptions of the parties and candidates. In 2016 , only about $5 \%$ of all respondents had nothing at all to say to any of the open ended 
questions - a figure in line with past benchmarks going back to the 1950s. As Wattenberg, Kelly, Geer, and others have noted, since the 1980 s more respondents have typically mentioned considerations about candidates than about parties. In the 1980s the contrasting figures ran on the order of 91-96 percent versus 67-90 percent, a fact that has been widely taken as a sign of a disconnect between citizens and the parties. ${ }^{50}$ In 2016, rates of non-response on the parties questions were far higher than on the candidates: 59 percent as against just 6 percent.

Where Clinton is concerned, one issue stands out: Corruption. Fully $18 \%$ of all respondents offering any comment on Clinton (comprising $10 \%$ of the total respondent pool) mentioned this concept. Here the disjunction between explicit term and broader concept is much narrower than usual: many respondents directly employed the term itself. In a nationwide survey of diverse, disconnected respondents, we consider this $18 \%$ figure to be stunning. Evidently the famous Bannon-inspired book by Peter Schweitzer - widely publicized in both the right-wing and the mainstream media - together with Trump's frequent references to "crooked Hillary" and "the most corrupt candidate in history," had powerful effects. ${ }^{51}$ No closed-ended ANES item that we are aware of reveals this preoccupation so clearly.

Donald Trump also inspired strong opinions. But they varied widely. Mentions of strong leadership were definitely common, expressed in a variety of terms and from a variety of perspectives. One indicator: about $12 \%$ of all those offering comments about Trump praised his "power," "action," "straight-shooter" character, or "brutal" honesty. Mentions also abound indicating that respondents expected that Trump would be more active in keeping the country "safe" and in "saying what the [public] is scared to say." 52 (Note that a closed-ended "strong leader" item showed up as important in some of our quantitative analyses.) 
Our work with open ended questions brought home to us the importance of a set of issues that has thus far played surprisingly little part in scholarly discussions of 2016 voting: issues concerning international trade, globalization, plant relocation, and imports. We have already noted the importance of the "limit imports" closed-ended item in both primary and general election voting. Our study of open-ended questions raised important questions about assessments in this area. First, the gap between common speech and "elite discourse" on these subjects is unusually wide - much wider than one would glean from responses to closed-ended survey questions about trade and globalization.

These topics are also refractory to simple word counts. Only occasionally do explicit comments about "free trade" crop up in the interviews: perhaps only 25 mentions in the entire data set. But this is quite misleading as a guide to the true extent of public concerns about the topic. Terms and expressions related to free trade are in fact are variegated, and fairly common. Most of them occur as either admiring comments about Trump or critical remarks about Clinton. (A handful are scattered among references to the parties.) We estimate that 7\% of all respondents, across all the candidate and party questions, alluded to free trade, globalization, or closely similar themes. (This makes up 3\% of the total respondent pool.) In a nationwide sample with no prompting, this strikes us as a significant figure. It may be useful to note that broader mentions of economic concerns are the most common of any general topic, appearing among $15 \%$ of respondents across the entire data set.

Our comparison of respondents' answers to the closed- and open-ended questions also brought to light a striking ambivalence in popular attitudes that has apparently mostly escaped notice. It is obvious that - with certain recent caveats in regard to China - since the New Deal 
the corporate mainstream, the mass media, and conventional economics have all treated free trade as the incarnation of sound public policy and right thinking. As reactions to Trump's trade proposals as president confirm, doubters rarely receive other than derisive attention in the major media.

The heavy weight of the official mind on this topic appears to have percolated down to many voters. When we checked for consistency between open-ended responses and responses to canned, closed ended questions about whether or not more trade is good, or whether reciprocal trade treaties make sense, we found that many who spontaneously expressed qualms in response to the open-ended questions nonetheless voiced agreement with the generalized pro-trade sentiments embodied in closed questions. Only the direct question about limiting imports (a substantial predictor of voting choices) tended to draw consistent responses, though that, too, only partly mirrors the skepticism voiced in the open ended questions.

Our conclusion is that these divergently expressed sentiments reflect real ambivalence in voter stances and raise some problematic methodological questions. We suspect that many voters (like, occasionally, Trump himself) profess to believe in free trade when it is also "fair trade," or consider "free trade" in the abstract to signify a Good Thing. They accordingly qualify their responses to the closed-ended questions in ways that are difficult to pick up from the prima facie wording, even as they want relief from imports in various forms. As we discuss later in this paper, such a view appears to have been an important ingredient in decisions by many whites who voted for Obama in 2012 to switch and vote for Trump in 2016, as well (as we have noted) as for many primary voters to support Trump. 


\section{Economic Distress and Congressional Districts}

It is no secret that much of middle America has long suffered economic distress. Starting around the early 1970s, the "rust belt" in particular - but also much of rural America has experienced the shuttering of factories and small businesses; job losses; stagnant or declining wages; departures by young people; and the hollowing out of whole communities. Families, already hard-pressed to pay their bills, have been devastated by unexpected traumas from layoffs, medical emergencies, or the loss of retirement pensions. Young people, if lucky enough to get into college, have been burdened with enormous student loan debts. Some distressed Americans have resorted to opioids or suicide. In this rich county, life expectancies have dropped among certain groups - especially older white men. ${ }^{53}$

Economic distress appears to have reached a peak after the 2007-2008 financial crisis and Great Recession, when many families were unable to make mortgage payments and thousands lost their homes to foreclosures. Recovery from the Great Recession was disappointingly slow and uneven; the wealthiest Americans rather quickly recouped their riches, while most of their fellow countrymen continued to be mired in economic troubles. Despite high hopes for the new Obama administration that was elected in 2008, politicians in Washington came to be seen as more eager to help their big-money donors (including "too big to fail" banks) than to help under-water homeowners or distressed workers. Looking back at the second decade of the twenty-first century, it seems clear that the United States was becoming ripe for populistic revolt. ${ }^{54}$

Using aggregate data - mainly at the county level - a number of economists, public health experts, sociologists and others have documented the geographic unfolding of this 
economic distress and its expression in rising opioid use and suicide rates, along with declining life expectancies. Many have investigated its causes. ${ }^{55}$

Economists have suggested that the causes of distress have included fundamental economic and technological shifts in the country. One is a sharp rise in global economic competition from low-wage countries abroad, which has undercut U.S. jobs with imports of cheap goods and lured U.S. capital to move abroad and set up business there, accelerating the pressure on U.S. jobs and wages. Economists studying both the U.S. and other countries have found direct political effects of imports on voting for Trump and other Republicans.

Automation, too, may have displaced substantial numbers of Americans from well-paid jobs, though it is likely that it saves at least some other jobs. Efforts by businesses to off-shore or contract out within the United States larger and larger amounts of work formerly performed by U.S. employees has led to substantial declines in wages. Government policies (e.g., at the National Labor Relations Board, along with macroeconomic austerity) have powerfully accelerated this process, as has the focus on "shareholder value" among American corporations. 56

Other scholars have implicated home mortgage difficulties in the rise of Trump, and still others have pointed to the whole configuration of economic distress (including suicides, opioids, and declining life expectancies) as tending to produce high levels of Trump support. ${ }^{57}$

Some social scientists have greeted such findings with the skeptical observation that ecological inference has its hazards: lots of things were going on at once in these distressed areas, and aggregate data are not ideal for sorting out which ones mattered how much in the minds of voters. We agree. Ultimately we plan to link aggregate and survey data in such a way 
that we can untangle what actually motivated individuals' voting decisions and what led to those motivations.

At minimum, however, the aggregate findings are highly suggestive. They suggest that there were several large elephants in the room, and that some of them likely had substantial impacts on the 2016 populist revolt that brought Donald Trump to the presidency.

As a first step toward bringing together aggregate- and individual-level-data, we have conducted our own aggregate study of geographical units: in our case, congressional districts, which are highly relevant politically and can be directly linked to ANES data about individual survey respondents.

\section{Congressional districts and 2016 Trump voting.}

Certain kinds of aggregate data are available only at the county level, but the insatiable appetite of House members for data on their districts (especially for data that might show benefits from their pet projects or programs) has inspired various government bureaus to publish a fair amount of data. Unfortunately, however, the decennial reallocations of congressional seats between states, and the redrawing of district lines within states, severely limit the use of these data over time. Without substantial adjustments, long time series are generally not to be had. This is particularly true of some variables that we consider especially important, such as rates of economic growth over the long run. Using aggregate congressional district data also brings with it a host of complex statistical problems. It is important, for example, to test and adjust for spatial autocorrelation, since important phenomena can spill across district lines. Nonetheless, our analyses of these data have been fruitful. 
Our data confirm the widespread impression that troubles of many kinds have tended to cluster in the same congressional districts, with many of them located in rural America (particularly in border states and the south) or in the "rust belt." We are chiefly interested in precisely which factors, social and/or economic, have made how much difference in producing Trump votes. For this we need to perform spatial regression analyses at the aggregate (congressional district) level.

Some findings from spatial regressions (with OLS results also given for comparison) are displayed in Table $6 .^{58}$ This relates fundamental economic characteristics of congressional districts - namely the relative size of a handful of industrial sectors in each district - to Trump voting in 2016. Large oil and gas, coal, agriculture, and manufacturing sectors all had positive influences on size of the aggregate Trump vote, and the information sector had a strong negative influence.

[Table 6 about here]

Clearly district industrial structure made a big difference: Even in a simple OLS analysis, these sectors account for more than a third of the variance across districts in Republican vote share, while in the spatial model - which takes better account of the effects of neighboring districts - industrial structure accounts for still more of the variance in vote shares. Several coefficients are highly significant and large - notably including those for the oil and gas sector (a Republican mainstay in 2016, which Trump championed); the manufacturing sector (battered by imports that were decried by Trump alone among 2016 candidates); and agriculture (another Republican mainstay, including many rural communities that had been particularly 
devastated by economic distress. More than a few had failed to participate in the anemic recovery of the Obama years). These results strongly suggest that economics mattered.

Table 7 displays an alternative modeling approach keyed to social groups and demographic variables, including some with obvious relations to economic structures as well as long-term party loyalties. Here even more of the across-district variance in Trump's vote share is accounted for: more than four fifths of it. Districts with many veterans, many high-schoolonly residents (in contrast to those with either more or less formal education), or many Evangelicals, produced many Trump votes. On the other hand, districts with many African American or Hispanic residents (substantial numbers of whom have low incomes) tended to side with the Clinton, the Democrat.

(Table 7 About Here)

We cannot be certain precisely why the presence or absence of each of these groups affected Trump voting the way it did. But the results fit with Trump's unique campaign stands as well as with long-term party divisions. Trump's promise to "make American great again," for example, likely resonated with veterans - who also tended to be older and to be on the receiving end of economic distress. Their influence seems to have been especially strong where they represented relatively large shares of eligible voters, as opposed to a high percentage of the population as a whole. Trump's economic stands clearly appealed to many high-schoolonly workers, who were particularly vulnerable to job competition from imports. ${ }^{59}$ Trump's espousal of social conservatism (despite his own conspicuous lack of religiosity or conventional morality), and his explicit commitments to modify laws they detested, no doubt tended to attract Evangelicals. ${ }^{60}$ 
By contrast, Trump's denigration of immigrants from Mexico surely cost him support from Hispanics, even beyond their prior tendency to support Democrats. Similarly, his barely disguised racism, his appeals to white nationalism, and his opposition to government programs that were important to African Americans, undoubtedly tended to turn off African Americans, who in any case had mostly been Democrats for years.

\section{Switches toward Trump among congressional districts}

Just as we noted in connection with individual-level voting, however, the level of Trump support in 2016 is a very imperfect indicator of the appeal of Trump's brand of right-wing populism, as opposed to the generic appeal of Republican vs. Democratic candidates. Some pro-Trump districts might have voted for a yellow dog as long as that dog was not a Democrat.

To assess the unique appeal of Trump-style populism it is more helpful to analyze changes in the level of districts' support for Republican presidential candidates. Given the considerable similarities between Democratic candidates Obama and Clinton in 2012 and 2016 (particularly in terms of their issue stands and their group allegiances), an increase or decrease in Trump's vote share (compared to the share won four years earlier by establishment Republican Mitt Romney) should mostly signal the appeal of Trumpian populism in each district. The predictors of such increases or decreases should help us understand the roots of that populism's appeal or lack of appeal to the broad American electorate.

Accordingly, we performed a series of aggregate spatial regressions on the change in Republican vote share (between 2012 and 2016) by congressional district. The most important 
results are reported in Table 8, which zeroes in on several specific and highly relevant predictors and accounts for very substantial portions of the variance.

(Table 8 About Here)

The first spatial regression makes clear that drops (or below-average gains) in median incomes or employment levels in districts led to more Trump (2016) than Romney (2012) votes. So did higher proportions of district bridges that were judged to be "structurally deficient" - a subtle and interesting indicator of the inability or unwillingness of state or local funders to repair infrastructure. (And, perhaps, of the effects of a politically imposed "tax squeeze"). Such fiscally starved districts tended to shift votes toward Trump. Districts with substantial Mormon populations, on the other hand, were less attracted by Trump (whom several of their elders had criticized) than they had been to the Mormon Mitt Romney in 2012.

The second spatial regression in Table 8 confirms these points and adds another: that a drop over four years in the number of business establishments in a district led to substantially more votes for Trump than Romney had won four years earlier. ${ }^{61}$

All in all, these district-vote-change regressions provide the strongest evidence we have yet discussed for the proposition that growing economic distress - or a sense of being left behind in an uneven recovery - was an important factor in the appeal of Trump-style populism. But this cannot be the end of the story.

\section{Back to Individual-level Data: Predicting Changes in Voting Decisions}

The aggregate vote-change findings considerably bolster our conclusion that economic as well as social factors were quite important in 2016. As we have acknowledged, however, the 
search for roots of support for populism among individuals must ultimately focus on analyses of individuals' attitudes and behavior. Such analyses are most effectively conducted by using individual-level survey data. Accordingly we return to the 2016 ANES data. But we do so bearing in mind an important lesson from our aggregate analyses: that the analysis of changes over time in attitudes and behavior is more likely to illuminate the roots of populism than is the more usual static type of analysis.

Fortunately, ANES asked 2016 voters what they had done in 2012: whether they voted for Obama, or for Romney, or did not vote. Of course, people's recollections of their actions four years earlier are subject to various errors, including wishful thinking as well as simple failures of memory. (For example, the victors in presidential elections regularly "win" more recalled votes four years later than they had won in the actual election. ${ }^{62}$ ) Still, the recall data appear to be sufficiently reliable to be worth analyzing. Indeed, there may be good reasons to prefer them to the so-called "validated vote" data, which we have also examined. ${ }^{63}$

Using the ANES recall data, it is a simple matter to record reported changes in behavior between 2012 and 2016. Vote switching can come in different forms, of course. Some people directly switched from voting for Obama to supporting Trump. Other people came in from the cold: they switched from non-voting in 2012 to voting for Trump in 2016. Or they went out into the cold: they changed from voting for Obama in 2012 to non-voting in 2016. The latter two groups helped Trump roughly half as much as the straight switchers from Obama to Trump voting. ${ }^{64}$

We discovered that the different sorts of switchers tended to come from different groups of people. The influences on their behavior varied as well. To be sure, racists and sexists 
(along with those who occupied apparently racist or sexist positions on those scales for reasons of policy or ideology rather than prejudice) did indeed rally around Trump, as our tables indicate. But these factors can explain only part of his appeal.

(Tables 9 and 10 About Here)

In addition, just as one would expect, both switching from Obama to Trump and switching from non-voting to casting a ballot for Trump were strongly predicted by feelings that the country was on the "wrong track," feelings that were likely fueled by a combination of social and economic discontent. Switchers from Obama to Trump were also swayed by feelings that the US "needs a strong leader," and that the United States was now "less secure." Residing in congressional districts that were relatively left out of the Obama recovery also appears to have played a role in the switchers' decisions. ${ }^{65}$

Both new voters who went for Trump and those who switched from voting for Obama also favored protection from imports. Whites who had voted for Obama were particularly affected by this view - there was a statistically significant interaction. Since they had voted for Obama (an African American), racial resentment seems unlikely to have been the only important determinant of their moves toward Trump; fears about import pressures on wages seem pertinent. Voters who had not voted in 2012 but came out for Trump were moved mostly by the same factors, but also by the opinion that the government should guarantee jobs - another testament to the leftward nods included in Trump's brand of populism and perhaps an indication of disappointment with the results of eight years of Democratic control of the White House. 
Another factor appears to have affected both sets of new Trump voters - one that has thus far received almost no attention. As late as early October, not only many polls, but also the lowa Electronic Market betting odds, suggested that the Democrats had a serious chance of winning control of the Senate. In the final weeks of the campaign, however, a wave of money supporting Republican candidates poured into many races. In a dramatic turnaround, the Republicans retained control of the Senate. This came with a striking twist: for the first time in American history, the alignment of winning Senate candidates with the outcome of the presidential race within the state was perfect - the same party won both, with no exceptions. ${ }^{66}$

Observing a strikingly similar wave of last-minute money on behalf of the Trump campaign, Ferguson, Jorgensen, and Chen have proposed that the two waves reinforced each other, helping Trump to overcome the Clinton lead. Our evidence supports this "reverse coat tails" effect. ${ }^{67}$ Having a GOP Senate campaign in the state appears to have strongly affected new voters for Trump, both those who voted for Obama in 2012 and those did not vote in 2012.

The third type of switch that helped elect Trump involved voters who voted for Obama in 2012 but then did not vote in 2016. Our Table 11, together with our analyses of their other characteristics, is quite interesting in what they suggest about these people. Firstly, very few conservative voters took this path, as one might expect of people who had all voted for Obama. Almost all of them were either liberal or moderate in their views - in other words, good prospects for casting another Democratic vote. But these "into the cold" voters, who had tuned in but then turned off and dropped out, were often poor - living on the margins of existence in America. It is true that they appeared to be very slightly more sexist than most Democrats. But they were also rather heavily female. Our suspicion is that the sotto voce rumblings were right: 
the Wall Street orientation and affluent tilt to the Clinton campaign detracted from Clinton's appeal to less affluent voters. Buttressing this suggestion is the fact that, as a group, this bloc of non-voters tended not to perceive important differences between the two major parties.

(Table 11 About Here)

The regression analysis reported in Table 12 estimated the independent impacts of such factors. 2012 Obama voters who abstained in 2016 tended to score highly on racial resentment scales, but also favored limiting imports, considered the U.S. to be less secure, and did not approve of the Affordable Care Act (which, given their relatively liberal orientations, we suspect was out of disappointment with its provisions, rather than a conservative rejection of the idea). They also tended to be young, to have lower incomes, and to see little difference between the parties.

(Table 12 About Here)

Our data also permit us to offer an answer a much-pondered question: What did Bernie Sanders' primary voters do? Here we doubt that recall errors were much of a factor; the whole imbroglio had been very recent, and people who told pollsters around election day that they had been Bernie primary voters were certainly not retrospectively going with a winner. As Table 13 shows, we found that about $10 \%$ of Sanders primary voters cast general election votes for Trump, and another $10 \%$ did not vote. This is a substantial impact, we think, and, once again, suggestive about whether more forceful economic appeals by Clinton might have helped her. ${ }^{68}$ (Table 13 about here)

What Influenced Social Attitudes? 
We have left for last an important question that we cannot yet answer: what impact, if any, did accumulating economic distress have upon the social attitudes (e.g. racial resentment and modern sexism) that we found to be important in 2016 voting decisions and in individuals' switches from 2012 to 2016 ?

From the earliest days of our study we have suspected that part of the solution to the “social vs. economic?" puzzle is that both types of factors were important in 2016, but that economic factors - especially economic distress caused by import pressure, plant relocation, and other mechanisms that have restrained wage growth - were important long-term influences upon the social attitudes that had big proximate effects on 2016 voting.

In order to pin down the extent of any such effects we need to consider more fully the dynamic interplay of economic, social, and political factors over time. And we need to estimate fully multi-level models that take into account both geographical contexts and individuals' attitudes and characteristics. This is a challenge, particularly when coping with spatial autocorrelation across congressional districts and with complex weighting schemes for the individual survey data. One of the principal aims for our future work is to do it. We also need to explore more carefully the distraction/ manipulation hypothesis: that politicians and others deliberately channeled economic distress to exploit, amplify, or even create social resentments.

\section{Conclusion}

The conventional wisdom is wrong, or at least seriously incomplete. Donald Trump was not elected president of the United States by an avalanche of "deplorables" motivated only by racism, sexism and xenophobia. 
To be sure, social anxieties and resentments were important, especially in the 2016 Republican primaries - an "alternative universe" populated by a relatively small, intense band of activists who were indeed susceptible to such appeals. In the general election, too, racism and sexism affected voters, though to a much lesser extent and with decidedly double-edged impact. (Most Americans are not extreme sexists or racists. The net effect of Trump's racerelated appeals is unclear, and he almost certainly lost rather than gained general election votes due to his perceived sexism.) Without question, Trump's scapegoating message did activate and exploit social resentments that affected voting behavior.

At every stage of the 2016 elections, however, economic factors also played a big part. Possibly even a bigger part. Over the course of several decades, and especially during and after the Great Recession, millions of Americans had suffered from job losses, stagnant or declining wages, home foreclosures, medical crises, and hollowed-out communities. Many - not without reason - blamed economic globalization, cheap imports, the immigration of low-wage workers, and automation. Many were fed up with both major parties, both of which had backed free international trade and high levels of immigration without, apparently, a lot of concern for those who were negatively affected.

Our findings, based on several different types of data and styles of analysis (individualand aggregate-level data; closed-ended and open-ended survey questions; analyses of primary voting, general election voting, and changes between 2012 and 2016) make clear that Trump's economic-based appeals were central to his success. Particularly his uniquely populist focus on trade and immigration. In the Republican primaries, in the general election, and in changes 
from 2012, we repeatedly found that key economic factors had big effects on voting decisions and on aggregate congressional district vote totals.

Attitudes about limiting imports emerged as particularly important, in the primaries, the general election, and among 2016 switchers or abstainers who had voted for Obama in 2012. Because of Trump's leftward nods, desires to reduce income inequality and concerns that politicians only care about the rich moved GOP primary voters toward Trump rather than establishment Republican candidates. Opposition to job guarantees also appears to have pushed some 2012 non-voters to turn out for Trump in 2016 (which we interpret as reflecting support from adherents of the Tea Party movement inside the Republican Party).

Many economic factors affected aggregate vote totals across congressional districts, including the size of certain industrial sectors (e.g. manufacturing, battered by cheap imports). Aggregate 2012-2016 shifts in congressional district vote-shares from Romney toward Trump were moved by low median incomes, negative changes in employment, starved public works (measured by structurally deficient bridges), and negative changes in the number of business establishments.

How could so many leading political scientists have missed these economic factors? Partly, no doubt, because few have investigated the impact of aggregate economic changes over time. Partly also, we suspect, because they have not looked hard enough, even within the ANES data. Most have relied upon certain ever-popular measures of short-term economic attitudes and perceptions, such as reported perceptions of personal or national economic changes over just a single year. Those perceptions are known to be error-ridden, subject to 
partisan and other biases. They do not well capture the sorts of long-term economic distress that we emphasize. It is not surprising that they had little connection to Trump voting.

Not only were several major economic factors important; our analyses make clear that the social and the economic were intertwined, both in Trump's rhetoric and in the minds of many voters. The boundaries between the two are fuzzy. Sharp distinctions can be misleading.

This is particularly clear in responses to the ANES open-ended "likes" and "dislikes" questions, which allow people to spontaneously express their own views rather than be boxed in by the elite-designed wording of closed-ended questions. Not only did many Americans express worries about trade and immigration in non-standard ways; many alluded to the complex mixture of social and economic anxieties involved in reactions to immigration: unease about different-looking and differently speaking foreigners, but also concern about job competition. What could superficially appear to be xenophobic views of Mexicans or Muslims sometimes instead reflected genuine (if exaggerated) worries about jobs or about potential terrorism. Much the same thing is true of certain attitudes that can sound racist: mistaken but understandable perceptions of affirmative action, for example, can lead to resentment of African Americans and opposition to policies seen as unfairly benefiting them. ${ }^{69}$

Ambiguities and intertwining between social and economic factors can also be discerned when analyzing closed-ended questions about the proposed Wall against Mexico, opposition to Syrian refugees, or sentiments that the country is on the "wrong track."

We suspect that this intertwining of the social and the economic partly reflects dynamic processes that work over many years, in which economic and social factors reciprocally influence each other. We also suspect that fundamental economic trends (economic 
globalization, technological advances) may have been even more important than social trends (increased ethnic diversity, advances by women and minorities) in fueling increased social resentments - particularly if something like Arendt's "alliance of mob and capital" takes shape, wherein wealthy elites deliberately inflame (even create) and channel economic distress into social resentments. Our analysis of Trump's scapegoating hints at this. But to untangle the dynamic processes will require different data than we have at present. These are issues for the future.

What does the 2016 election tell us about the mass roots of right-wing populism?

Despite the inherent limitations of data that rest upon citizens' comparative judgments of particular populists versus particular, specific opponents (establishment Republican presidential contenders; baggage-laden Hillary Clinton), our findings do help illuminate some sources of the mass appeal of Trump's particular sort of right wing-populism. (In talking about Trump's "appeal," of course, one should never forget that he was generally unpopular, and actually won fewer voters' support than did the almost equally unpopular Clinton.)

Above all, our evidence makes clear that economic aspects of Trump's message - often explicitly linked to more or less plausible policy proposals - were central. His deviations from Republican orthodoxy on trade and immigration were crucial in the primaries and powerful in the general election as well. His nods to criticisms of the wealthy and support for left-leaning economic policies (on infrastructure, jobs, Social Security and Medicare) undoubtedly helped defuse the usual advantage they bring to Democrats in general elections.

We believe that future analyses of right-wing populism in other countries would do well to more deeply probe the economic side of populist appeals. In European countries where 
immigration has aroused widespread rebellion, for example, scholars would do well to more carefully parse out how much distress has reflected social and cultural resentment of foreign immigrants, and how much has proceeded from worry about their economic impact.

The difference matters for practical as well as scientific reasons. In Europe, as in the United States, it bears directly upon how one might combat the rise of right-wing populism. Would broader economic appeals help or not? In the U.S., should the Democrats just embrace ethnic and gender diversity and count on favorable demographic trends? Or should they try to win back white working class voters through left-oriented economic policies on jobs, wages, health care and the like? Our findings suggest that the latter strategy, combined with cautious treatment of immigration and international trade, might bear some fruit. 
Table 1. Predictors of Voting for Trump in the 2016 Primary.

\begin{tabular}{|c|c|c|c|c|}
\hline VARIABLES & $\begin{array}{c}(1) \\
\text { Vs. Other } \\
\text { GOP } \\
\text { Candidates } \\
\end{array}$ & $\begin{array}{c}(2) \\
\text { Vs. Other } \\
\text { GOP } \\
\text { Candidates } \\
\end{array}$ & $\begin{array}{c}\text { (3) } \\
\text { Vs. Other } \\
\text { Primary } \\
\text { Candidates }\end{array}$ & $\begin{array}{c}\text { (4) } \\
\text { Vs. Other } \\
\text { Primary } \\
\text { Candidates }\end{array}$ \\
\hline Right Track & & & $\begin{array}{c}-0.872 * * \\
(0.358)\end{array}$ & $\begin{array}{c}-0.886^{* *} \\
(0.347)\end{array}$ \\
\hline Limit Imports & $\begin{array}{c}0.680 * * * \\
(0.249)\end{array}$ & $\begin{array}{c}0.771 * * * \\
(0.244)\end{array}$ & $\begin{array}{c}0.721 * * * \\
(0.233)\end{array}$ & $\begin{array}{c}0.757 * * * \\
(0.217)\end{array}$ \\
\hline Modern Sexism & & & $\begin{array}{c}0.879 * * \\
(0.394)\end{array}$ & $\begin{array}{l}0.933^{*} \\
(0.525)\end{array}$ \\
\hline Racial Resentment & & & $\begin{array}{c}1.600 * * * \\
(0.386)\end{array}$ & $\begin{array}{c}1.736^{* * *} \\
(0.485)\end{array}$ \\
\hline Need Strong Leader & & & $\begin{array}{c}1.733 * * * \\
(0.356)\end{array}$ & $\begin{array}{c}1.889 * * * \\
(0.358)\end{array}$ \\
\hline White & & & $\begin{array}{c}0.728 * * \\
(0.291)\end{array}$ & $\begin{array}{c}0.769 * * * \\
(0.272)\end{array}$ \\
\hline US Less Secure & & & $\begin{array}{c}0.870 * * * \\
(0.240)\end{array}$ & $\begin{array}{c}0.934 * * * \\
(0.252)\end{array}$ \\
\hline Build Wall w/ Mexico & $\begin{array}{c}1.384 * * * \\
(0.360)\end{array}$ & $\begin{array}{c}1.491 * * * \\
(0.402)\end{array}$ & & \\
\hline Allow Syrian Refugees & $\begin{array}{c}-1.850 * * * \\
(0.520)\end{array}$ & $\begin{array}{c}-1.989 * * * \\
(0.527)\end{array}$ & & \\
\hline Gov't Should Reduce Ineq. & $\begin{array}{c}1.109 * * * \\
(0.390)\end{array}$ & $\begin{array}{c}1.243 * * * \\
(0.390)\end{array}$ & & \\
\hline Politicians Only Care About Rich & $\begin{array}{l}0.717^{*} \\
(0.363)\end{array}$ & $\begin{array}{c}0.774 * * \\
(0.375)\end{array}$ & & \\
\hline Constant & $\begin{array}{c}-1.949 * * * \\
(0.415)\end{array}$ & $\begin{array}{c}-2.146^{* * *} \\
(0.474)\end{array}$ & $\begin{array}{c}-5.276^{* * *} \\
(0.414)\end{array}$ & $\begin{array}{c}-5.686^{* * * *} \\
(0.448)\end{array}$ \\
\hline $\begin{array}{l}\mathrm{N} \\
\text { Pseudo-R }{ }^{2}\end{array}$ & $\begin{array}{c}1,216 \\
.17 \\
\end{array}$ & & $\begin{array}{c}1,856 \\
.26 \\
\end{array}$ & \\
\hline
\end{tabular}

Note: Cell entries are 0-1 standardized logit coefficients. (1) and (3) are based on survey logistic regressions while (2) and (4) are based on mixed logistic regressions with survey weights at the first level as discussed in note 36 . Standard errors in parentheses $* * * \mathrm{p}<0.01, * * \mathrm{p}<0.05, * \mathrm{p}<0.1$ 
Table 2. Opinions of GOP Primary Voters vs. the Population.

\begin{tabular}{lcc}
\hline & $\begin{array}{c}\text { GOP Primary } \\
\text { Voters }\end{array}$ & Population \\
\hline Wrong track & $94 \%$ & $74 \%$ \\
Trump video should matter a lot or great deal & $13 \%$ & $44 \%$ \\
Favor building wall & $63 \%$ & $33 \%$ \\
Obama not Muslim & $30 \%$ & $50 \%$ \\
Disagree that slavery's legacy makes things hard & $63 \%$ & $41 \%$ \\
Oppose Syrian refugees & $77 \%$ & $50 \%$ \\
US world position is weaker & $86 \%$ & $54 \%$ \\
Very/extremely likely immigration takes jobs & $53 \%$ & $37 \%$ \\
Favor free trade agreements & $37 \%$ & $38 \%$ \\
\hline
\end{tabular}


Table 3. Weighted Racial Resentment Means, ANES 2008-2016

\begin{tabular}{lccc}
\hline & 2008 & 2012 & 2016 \\
\hline Overall Mean & 3.46 & 3.52 & 3.19 \\
Republican Mean & 3.84 & 3.99 & 3.78 \\
Democrat Mean & 3.16 & 3.11 & 2.63 \\
GOP Primary Voter Mean & - & - & 3.84 \\
Trump Primary Voter Mean & - & - & 3.99 \\
\hline
\end{tabular}

Note: Racial resentment ranges from 1 (least resentful) to 5 (most resentful.) 
Table 4. Weighted Modern Sexism Means, ANES 2008-2016

\begin{tabular}{lccc}
\hline & 2008 & 2012 & 2016 \\
\hline Overall Mean & 2.54 & 2.48 & 2.34 \\
Republican Mean & 2.60 & 2.71 & 2.66 \\
Democrat Mean & 2.36 & 2.26 & 2.03 \\
GOP Primary Voter Mean & - & - & 2.65 \\
Trump Primary Voter Mean & - & - & 2.74 \\
\hline
\end{tabular}

Note: modern sexism ranges from 1 (least sexist) to 5 (most sexist.) 
Table 5. Predictors of 2016 General Election Voting

\begin{tabular}{|c|c|c|c|c|c|c|}
\hline VARIABLES & $\begin{array}{c}\text { (1) } \\
\text { Basic Model }\end{array}$ & $\begin{array}{c}(2) \\
\text { Basic Model }\end{array}$ & $\begin{array}{c}\text { (3) } \\
\text { With Party ID }\end{array}$ & $\begin{array}{c}\text { (4) } \\
\text { With Party ID }\end{array}$ & $\begin{array}{l}\text { (5) } \\
\text { With Party ID \& } \\
\text { Demographics }\end{array}$ & $\begin{array}{l}\text { (6) } \\
\text { With Party ID \& } \\
\text { Demographics }\end{array}$ \\
\hline Right Track & $\begin{array}{c}-2.273 * * * \\
(0.282)\end{array}$ & $\begin{array}{c}-2.638 * * * \\
(0.359)\end{array}$ & $\begin{array}{c}-2.140 * * * \\
(0.397)\end{array}$ & $\begin{array}{c}-2.583 * * * \\
(0.497)\end{array}$ & $\begin{array}{c}-2.323 * * * \\
(0.440)\end{array}$ & $\begin{array}{c}-2.810^{* * *} \\
(0.545)\end{array}$ \\
\hline Limit Imports & $\begin{array}{c}0.903 * * * \\
(0.226)\end{array}$ & $\begin{array}{c}1.072 * * * \\
(0.218)\end{array}$ & $\begin{array}{c}1.040 * * * \\
(0.263)\end{array}$ & $\begin{array}{c}1.276^{* * *} \\
(0.280)\end{array}$ & $\begin{array}{c}1.095^{* * *} * \\
(0.288)\end{array}$ & $\begin{array}{c}1.375^{* * *} \\
(0.313)\end{array}$ \\
\hline Approve of ACA & $\begin{array}{c}-3.233 * * * \\
(0.270)\end{array}$ & $\begin{array}{c}-3.794 * * * \\
(0.354)\end{array}$ & $\begin{array}{c}-2.022 * * * \\
(0.342)\end{array}$ & $\begin{array}{c}-2.414 * * * \\
(0.372)\end{array}$ & $\begin{array}{c}-2.093 * * * \\
(0.374)\end{array}$ & $\begin{array}{c}-2.540 * * * \\
(0.405)\end{array}$ \\
\hline Racial Resentment & $\begin{array}{c}3.907 * * * \\
(0.365)\end{array}$ & $\begin{array}{c}4.531 * * * \\
(0.447)\end{array}$ & $\begin{array}{c}3.613 * * * \\
(0.506)\end{array}$ & $\begin{array}{c}4.284 * * * \\
(0.596)\end{array}$ & $\begin{array}{c}3.670 * * * \\
(0.588)\end{array}$ & $\begin{array}{c}4.435 * * * \\
(0.671)\end{array}$ \\
\hline Modern Sexism & $\begin{array}{c}4.081 * * * \\
(0.537)\end{array}$ & $\begin{array}{c}4.760 * * * \\
(0.636)\end{array}$ & $\begin{array}{c}3.558 * * * \\
(0.599)\end{array}$ & $\begin{array}{c}4.332 * * * \\
(0.739)\end{array}$ & $\begin{array}{c}3.637 * * * \\
(0.660)\end{array}$ & $\begin{array}{c}4.434 * * * \\
(0.767)\end{array}$ \\
\hline White & $\begin{array}{c}1.243 * * * \\
(0.248)\end{array}$ & $\begin{array}{c}1.427 * * * \\
(0.270)\end{array}$ & $\begin{array}{c}1.006 * * * \\
(0.255)\end{array}$ & $\begin{array}{c}1.135 * * * \\
(0.312)\end{array}$ & $\begin{array}{c}1.053 * * * \\
(0.306)\end{array}$ & $\begin{array}{c}1.188 * * * \\
(0.347)\end{array}$ \\
\hline Party ID & & & $\begin{array}{c}5.103 * * * \\
(0.468)\end{array}$ & $\begin{array}{c}6.135 * * * \\
(0.535)\end{array}$ & $\begin{array}{c}5.334 * * * \\
(0.540)\end{array}$ & $\begin{array}{c}6.516 * * * \\
(0.604)\end{array}$ \\
\hline Male & & & & & $\begin{array}{c}-0.040 \\
(0.242)\end{array}$ & $\begin{array}{c}0.086 \\
(0.285)\end{array}$ \\
\hline Age & & & & & $\begin{array}{c}0.318 \\
(0.607)\end{array}$ & $\begin{array}{c}0.653 \\
(0.692)\end{array}$ \\
\hline Income & & & & & $\begin{array}{c}-1.005 * * \\
(0.503)\end{array}$ & $\begin{array}{c}-1.102 * * \\
(0.530)\end{array}$ \\
\hline Religious Attendance & & & & & $\begin{array}{c}0.569 * * \\
(0.281)\end{array}$ & $\begin{array}{c}0.882 * * \\
(0.368)\end{array}$ \\
\hline Married & & & & & $\begin{array}{c}0.379 \\
(0.247)\end{array}$ & $\begin{array}{c}0.238 \\
(0.287)\end{array}$ \\
\hline Military Service & & & & & -0.056 & 0.002 \\
\hline
\end{tabular}




$\begin{array}{lccccc} & & & (0.306) & (0.410) & 0.342 \\ \text { Household Union } \\ \text { Membership }\end{array}$

Note: Cell entries are 0-1 standardized logit coefficients. (1), (2) and (3) are based on survey logistic regression while (2), (4) and (6) are based on mixed logistic regressions with survey weights at the first level as discussed in note 36 . Standard errors in parentheses. $* * * \mathrm{p}<0.01, * * \mathrm{p}<0.05, * \mathrm{p}<0.1$ 
Table 6. Effects on 2016 Aggregate Republican Presidential Vote by Congressional District (Spatial Durbin Model [SDM], $n=424$ )

\begin{tabular}{|c|c|c|}
\hline & OLS & SDM \\
\hline Intercept & $37.920(2.564)^{* * *}$ & $19.231(3.131)^{* * *}$ \\
\hline$\%$ agriculture & $1.083(0.324)^{* * *}$ & $1.381(0.343)^{* * *}$ \\
\hline$\%$ manufacturing & $0.888(0.155)^{* * *}$ & $1.661(0.194)^{* * *}$ \\
\hline$\%$ share of coal in electricity & $0.104(0.209)^{* * *}$ & $0.037(0.060)$ \\
\hline$\%$ employment oil and gas & $2.930(0.644)^{* * *}$ & $2.128(0.569)^{* * *}$ \\
\hline$\%$ information sector & $-3.728(0.676)^{* * *}$ & $1.006(0.755)$ \\
\hline $\begin{array}{r}\text { Spatially lagged } 2016 \text { Republican Presidential } \\
\text { vote share }(\rho)\end{array}$ & & 0.619 \\
\hline spatially lagged \% agriculture & & $-0.946(0.510)^{\prime}$ \\
\hline spatially lagged \% manufacturing & & $-1.404(0.254)^{* * *}$ \\
\hline spatially Lagged share of coal in electricity & & $-0.024(0.69)$ \\
\hline Lagged percent employment oil and gas & & $-0.257(0.915)$ \\
\hline Spatially lagged \% information & & $-4.461(1.040)^{* * *}$ \\
\hline AIC & 3386.249 & 3238.182 \\
\hline Multiple R-squared/pseudo-R-squared & 0.371 & 0.569 \\
\hline Moran's I Residuals & 0.356 & 0.007 \\
\hline Moran's I SD & $0.031^{* * *}$ & 0.030 \\
\hline
\end{tabular}


Table 7. Effects on Aggregate 2016 Republican Presidential Vote by Congressional District (Spatial Durbin Model (SDM), $n=433)$

\begin{tabular}{|c|c|c|}
\hline & OLS & SDM \\
\hline Intercept & $14.868(2.073)^{* * *}$ & $1.225(2.165)^{* * *}$ \\
\hline Evangelical & $0.698(0.38)^{* * *}$ & $0.4999(0.074)^{* * *}$ \\
\hline \% Hispanic2016 & $-0.233(0.022)^{* * *}$ & $-0.373(0.029)^{* * *}$ \\
\hline \% Black Non-Hispanic2016 & $-0.636(0.028)^{* * *}$ & $-0.762(0.025)^{* * *}$ \\
\hline$\%$ High School & $0.806(0.063)^{* * *}$ & $0.787(0.066)^{* * *}$ \\
\hline Veterans as \% of Eligible Voters & $1.090(0.149)^{* * *}$ & $1.094(0.166)^{* * *}$ \\
\hline $\begin{array}{r}\text { Spatially lagged } 2016 \text { Republican Presidential } \\
\text { vote share }(\rho)\end{array}$ & & 0.677 \\
\hline Spatially Lagged Evangelical & & $-0.288(0.087)^{* * *}$ \\
\hline Spatially Lagged \% Hispanic2016 & & $0.335(0.037)^{* * *}$ \\
\hline Spatially Lagged \% Black Nonhispanic2016 & & $0.636(0.045)^{* * *}$ \\
\hline Spatially Lagged \% high school & & $-0.397(0.098)^{* * *}$ \\
\hline Spatially Lagged veterans as $\%$ of eligible voters & & $-0.901(0.222)^{* * *}$ \\
\hline AIC & 2989.691 & 2767.275 \\
\hline Multiple R-squared/pseudo-R-squared & 0.801 & 0.884 \\
\hline Moran's I Residuals & 0.431 & 0.026 \\
\hline Moran's I SD & $0.031^{* * *}$ & 0.031 \\
\hline & \multicolumn{2}{|l|}{${ }^{* * *} p \leq .001$} \\
\hline
\end{tabular}


Table 8. Effects on Change in GOP Congressional District Vote Share, 2012-16 (Spatial Durbin Model (SDM N = 436)

\begin{tabular}{|c|c|c|c|c|}
\hline & OLS & SDM & OLS & SDM \\
\hline Intercept & $\begin{array}{c}6.739 \\
(.740)^{* * *}\end{array}$ & $\begin{array}{c}3.751 \\
(0.899)^{* * *}\end{array}$ & $\begin{array}{c}6.326 \\
(0.884)^{* * *}\end{array}$ & $\begin{array}{c}3.195 \\
(0.997)^{* *}\end{array}$ \\
\hline $\begin{array}{r}\text { Median Income in } \$ 1000 \text { s in Cong } \\
\text { Dist, change, } 2012 \text { to } 16\end{array}$ & $\begin{array}{l}-0.126 \\
(0.101)^{* * *}\end{array}$ & $\begin{array}{c}-0.139 \\
(0.011)^{* *}\end{array}$ & $(0.013)^{* * *}$ & $\begin{array}{l}-0.142 \\
(0.012)^{* * *}\end{array}$ \\
\hline Change in employment $2011-15$ & $\begin{array}{c}-0.170 \\
(0.034)^{* * *}\end{array}$ & $\begin{array}{l}-0.022 \\
(0.030)\end{array}$ & $\begin{array}{c}-0.122 \\
(0.053)^{*}\end{array}$ & $\begin{array}{c}0.007 \\
(0.040)\end{array}$ \\
\hline $\begin{array}{r}\% \text { of All Bridges Structurally } \\
\text { Deficient. } 2016\end{array}$ & $\begin{array}{l}0.205 \\
(0.034)^{* * *}\end{array}$ & $\begin{array}{c}0.113 \\
(0.038)^{* *}\end{array}$ & $\begin{array}{c}0.199 \\
(0.040)^{* * *}\end{array}$ & $\begin{array}{c}0.109 \\
(0.043)^{*}\end{array}$ \\
\hline$\%$ Mormon & $\begin{array}{l}-0.325 \\
(0.023)^{* * *}\end{array}$ & $\begin{array}{l}-0.345 \\
(0.053)^{* * *}\end{array}$ & & \\
\hline $\begin{array}{r}\% \text { Change in No. of Business } \\
\text { Establishments 2011-15 }\end{array}$ & & & $\begin{array}{l}-0.238 \\
(0.066)^{* * *}\end{array}$ & $\begin{array}{l}-0.095 \\
(0.052)\end{array}$ \\
\hline $\begin{array}{r}\text { Spatially Lagged Dif in GOP Vote } \\
2012-16(\rho)\end{array}$ & & $0.642^{* * *}$ & & $0.703^{* * *}$ \\
\hline $\begin{array}{r}\text { Spatially Lag. Median Income in } \\
\text { Cong Dis } 2012 \text { to } 16\end{array}$ & & $\begin{array}{c}0.096 \\
(0.015)^{* * *}\end{array}$ & & $\begin{array}{c}0.114 \\
(0.017)^{* * *}\end{array}$ \\
\hline $\begin{array}{r}\text { Spatially Lagged Change in } \\
\text { employment }\end{array}$ & & $(0.051)^{* * *}$ & & $\begin{array}{l}-0.145 \\
(0.074)\end{array}$ \\
\hline $\begin{array}{r}\text { Spatially Lagged Percent of all } \\
\text { bridges }\end{array}$ & & $\begin{array}{l}-0.113 \\
(0.054)^{*}\end{array}$ & & $\begin{array}{c}-0.147 \\
(0.061)^{*}\end{array}$ \\
\hline Spatially Lagged \% Mormon & & $\begin{array}{c}0.248 \\
(0.053)^{* * *}\end{array}$ & & \\
\hline $\begin{array}{r}\text { Spatially Lagged change in No. of } \\
\text { Businesses }\end{array}$ & & & & $\begin{array}{l}-0.051 \\
(0.095)\end{array}$ \\
\hline AIC & 2301.943 & 2124.415 & 2451.846 & 2237.393 \\
\hline $\begin{array}{r}\text { Multiple R-squared/pseudo-R- } \\
\text { squared }\end{array}$ & 0.567 & 0.719 & 0.390 & 0.635 \\
\hline Moran's I Residuals & 0.424 & 0.006 & 0.437 & 0.036 \\
\hline Moran's I SD & $.030^{* * *}$ & 0.030 & $0.030^{* * *}$ & 0.030 \\
\hline & \multicolumn{4}{|c|}{$p \leq .10,{ }^{*} p \leq .05,{ }^{* *} p \leq .01,{ }^{* * *} p \leq .001$} \\
\hline
\end{tabular}


Table 9

Predictors of Vote-Switching to Trump among 2012 Obama Voters

\begin{tabular}{|c|c|c|}
\hline Variables & $\begin{array}{l}\text { (1) } \\
\text { Switch from Obama in } \\
2012 \text { to Trump in } 2016\end{array}$ & $\begin{array}{c}\text { (2) } \\
\text { Mixed Logistic with } \\
\text { Survey Weight }\end{array}$ \\
\hline Right Track & $\begin{array}{c}-2.822 * * * \\
(0.507)\end{array}$ & $\begin{array}{c}-3.005 * * * \\
(0.559)\end{array}$ \\
\hline Racial Resentment & $\begin{array}{c}3.570 * * * \\
(0.784)\end{array}$ & $\begin{array}{c}3.864 * * * \\
(0.791)\end{array}$ \\
\hline Modern Sexism & $\begin{array}{c}4.011 * * * \\
(1.029)\end{array}$ & $\begin{array}{c}4.223 * * * \\
(1.228)\end{array}$ \\
\hline Limit Imports & $\begin{array}{l}-0.648 \\
(0.636)\end{array}$ & \\
\hline White & $\begin{array}{c}-0.140 \\
(0.712)\end{array}$ & $\begin{array}{c}1.566^{* * *} \\
(0.401)\end{array}$ \\
\hline Limit Imports $\mathrm{x}$ White & $\begin{array}{l}1.491 * \\
(0.817)\end{array}$ & \\
\hline Need Strong Leader & $\begin{array}{c}2.650 * * * \\
(0.597)\end{array}$ & $\begin{array}{c}3.346 * * * \\
(0.590)\end{array}$ \\
\hline US Less Secure & $\begin{array}{l}0.661^{*} \\
(0.335)\end{array}$ & $\begin{array}{c}1.115 * * * \\
(0.377)\end{array}$ \\
\hline Vote for GOP Senate Cand. & $\begin{array}{l}2.601 * * * \\
(0.381)\end{array}$ & $\begin{array}{l}3.074 * * * \\
(0.476)\end{array}$ \\
\hline $\begin{array}{l}\text { Median Earnings } 2013 \text { dollars in } \\
\text { cong district residing in }\end{array}$ & & $\begin{array}{c}-2.358 * * \\
(1.066)\end{array}$ \\
\hline Constant & $\begin{array}{l}-7.178 * * * \\
(0.888)\end{array}$ & $\begin{array}{c}-8.631 * * * \\
(0.980)\end{array}$ \\
\hline $\begin{array}{l}\mathrm{N} \\
\text { Pseudo-R }{ }^{2}\end{array}$ & $\begin{array}{c}1,550 \\
.37 \\
\end{array}$ & \\
\hline
\end{tabular}

Note: Cell entries are 0-1 standardized logit coefficients. (1) is based on survey logistic regressions while (2) is based on mixed logistic regressions with survey weights at the first level as discussed in note 36 . Standard errors in parentheses $* * * p<0.01, * * p<0.05, * p<0.1$ 
Table 10

Predictors of Voting for Trump among 2012 Non-Voters.

\begin{tabular}{|c|c|c|}
\hline Variables & $\begin{array}{c}\text { (1) } \\
2012 \text { Non-Vote to } 2016 \\
\text { Trump Vote }\end{array}$ & $\begin{array}{c}\text { (2) } \\
\text { Mixed Logistic with } \\
\text { Survey Weight }\end{array}$ \\
\hline Racial Resentment & $\begin{array}{c}2.002 * * * \\
(0.567)\end{array}$ & $\begin{array}{c}2.929 * * * \\
(0.886)\end{array}$ \\
\hline Modern Sexism & $\begin{array}{c}1.603 * * \\
(0.714)\end{array}$ & $\begin{array}{c}2.138 * * \\
(1.034)\end{array}$ \\
\hline Limit Imports & $\begin{array}{c}0.751 * * \\
(0.361)\end{array}$ & $\begin{array}{l}1.352 * * \\
(0.552)\end{array}$ \\
\hline Income & $\begin{array}{c}1.073 * * \\
(0.524)\end{array}$ & $\begin{array}{l}1.527 * * \\
(0.692)\end{array}$ \\
\hline US Less Secure & $\begin{array}{c}0.575 \\
(0.363)\end{array}$ & $\begin{array}{l}0.841^{*} \\
(0.485)\end{array}$ \\
\hline Gov't Should Guarantee Jobs & $\begin{array}{c}-1.380 * * \\
(0.594)\end{array}$ & $\begin{array}{c}-1.742 * * \\
(0.812)\end{array}$ \\
\hline Vote for GOP Senate Cand. & $\begin{array}{c}3.654 * * * \\
(0.407)\end{array}$ & $\begin{array}{c}5.565 * * * \\
(0.805)\end{array}$ \\
\hline Constant & $\begin{array}{c}-4.467 * * * \\
(0.805)\end{array}$ & $\begin{array}{c}-6.783 * * * \\
(1.175)\end{array}$ \\
\hline $\mathrm{N}$ & 1,133 & \\
\hline Pseudo- $\mathrm{R}^{2}$ & .34 & \\
\hline
\end{tabular}

Note: Cell entries are 0-1 standardized logit coefficients. (1) is based on survey logistic regressions while (2) is based on mixed logistic regressions with survey weights at the first level as discussed in note 36 . Standard errors in parentheses $* * * p<0.01, * * p<0.05, * p<0.1$ 
Table 11

Characteristics of 2012 Obama Voters Abstaining in 2016

\begin{tabular}{cc}
\hline Characteristic & Weighted Percent \\
\hline Black & 21 \\
White & 48 \\
Liberal & 36 \\
Moderate & 40 \\
Conservative & 24 \\
Female & 58 \\
\hline Characteristic & Weighted Mean \\
\hline Age & 42 \\
ANES Income Category & $12(\$ 35,000-\$ 39,999)$ \\
\hline
\end{tabular}


Table 12

Predictors of Voting for Trump among 2012 Non-Voters.

\begin{tabular}{lcc}
\hline \multirow{2}{*}{ VARIABLES } & $\begin{array}{c}(1) \\
\text { Non-Vote to } 2016 \\
\text { Trump Vote }\end{array}$ & $\begin{array}{c}\text { Mixed Logistic with } \\
\text { Survey Weight }\end{array}$ \\
\hline \multirow{3}{*}{ Racial Resentment } & $2.002^{* * *}$ & $2.929^{* * *}$ \\
Modern Sexism & $(0.567)$ & $(0.886)$ \\
& $1.603^{* *}$ & $2.138^{* *}$ \\
Limit Imports & $(0.714)$ & $(1.034)$ \\
& $0.751^{* *}$ & $1.352^{* *}$ \\
Income & $(0.361)$ & $(0.552)$ \\
& $1.073^{* *}$ & $1.527^{* *}$ \\
US Less Secure & $(0.524)$ & $(0.692)$ \\
Gov't Should Guarantee Jobs & 0.575 & $0.841^{*}$ \\
& $(0.363)$ & $(0.485)$ \\
Vote for GOP Senate Cand. & $-1.380^{* *}$ & $(0.812)$ \\
Constant & $(0.594)$ & $5.565^{* * *}$ \\
& $3.654^{* * *}$ & $(0.805)$ \\
N & $(0.407)$ & $-6.783^{* * *}$ \\
Pseudo-R & $-4.467^{* * *}$ & $(1.175)$ \\
\hline
\end{tabular}

Note: Cell entries are 0-1 standardized logit coefficients. (1) is based on survey logistic regressions while (2) is based on mixed logistic regressions with survey weights at the first level as discussed in note 36 . Standard errors in parentheses $* * * \mathrm{p}<0.01, * * \mathrm{p}<0.05, * \mathrm{p}<0.1$ 
Table 13

November Voting Behavior of Sanders Primary Voters

\begin{tabular}{cc}
\hline Behavior & Percent \\
\hline Vote for Clinton & 79 \\
Vote for Trump & 11 \\
Abstain & 9 \\
Total Sanders voters not voting for Clinton & 20 \\
\hline
\end{tabular}




\section{References}

Allen, Jonathan, and Amie Parnes. 2017. Shattered -- Inside Hillary Clinton's Doomed Campaign. New York: Crown.

Arendt, Hannah. 1973. The Origins of Totalitarianism. New York: Harcourt, Brace, Jovanovich.

Autor, David, David Dorn, Gordon Hanson, and Kaveh Majlesi. 2016. Importing Political Polarization? The Electoral Consequences of Rising Trade Exposure. In MIT Working Paper. Cambridge, Massachusetts: Massachusetts Institute of Technology.

Autor, David, David Dorn, Gordon Hanson, and Kaveh Majlesi. 2017. A Note on the Effect of Rising Trade Exposure on the 2016 Election. Cambridge, Massachusetts: Massachusetts Institute of Technology.

Berent, Mathew K., Jon Krosnick, and Arthur Lupia. 2016. "Measuring Voter Registration and Turnout in Surveys: Do Official Government Records Yield More Accurate Assessments?" Public Opinion Quarterly 80 (3):597-621.

Blair, Gwenda. 2015. The Trumps. Paperback Edition ed. Vol. Paperback Edition. New York: Simon \& Schuster.

Blake, Aaron. 2016. "Donald Trump's Best Speech of 2016, Annotated." Washington Post, August 19, 2016.

Buettner, Ursula. 2008. Weimar: Die ueberforderte Republik. Stuttgard: Klett Cotta.

Burnham, Walter Dean, and Thomas Ferguson. 2014. "Americans Are Sick to Death of Both Parties: Why Our Political System Is in Worse Shape Than We Thought." AlterNet, March 30, 2015, December 18, 2014. https://www.alternet.org/americans-are-sick-death-both-parties-whyour-politics-worse-shape-we-thought

Case, Anne, and Angus Deaton. 2017. Mortality and Morbidity in the Twenty-First Century. Washington, D.C.: Brookings Institution.

Dornbusch, Rudiger, and Sebastian Edwards. 1992. The Macroeconomics of Populism in Latin America. Chicago: University of Chicago Press.

Edwards, Sebastian. 2012. Left Behind: Latin America and the False Promise of Populism. Chicago: University of Chicago Press. Reprint, Reprint Edition.

Faris, Rob, Hal Roberts, Bruce Etling, Nikki Bourassa, Ethan Zuckerman, and Yorkai Benchler. 2017. Partisanship, Propaganda, and Disinformation: Online Media and the U.S. Presidential Election. Berkman Klein Center: Harvard University.

Ferguson, Thomas, and Robert Johnson. 2009a. "Too Big To Bail: The 'Paulson Put,' Presidential Politics, and the Global Financial Meltdown, Part I: From Shadow Banking System To Shadow Bailout, Part I." International Journal of Political Economy 38 (1):3-34.

Ferguson, Thomas, and Robert Johnson. 2009b. "Too Big To Bail: The "Paulson Put," Presidential Politics, and the Global Financial Meltdown Part II: Fatal Reversal- Single Payer and Back." International Journal of Political Economy 38 (2):5-45.

Ferguson, Thomas, Paul Jorgensen, and Jie Chen. 2017. Fifty Shades of Green: High Finance, Political Money, and the US Congress. New York: Roosevelt Institute. http://rooseveltinstitute.org/fifty-shades-green/

Ferguson, Thomas, Paul Jorgensen, and Jie Chen. 2018a. Industrial Structure and Party Competition in an Age of Hunger Games: Donald Trump and the 2016 Election. New York: Institute for New Economic Thinking Working Paper No. 66 https://papers.ssrn.com/sol3/papers.cfm?abstract id $=3125217$

Ferguson, Thomas, Paul Jorgensen, and Jie Chen. 2018b. "Industrial Structure and Political Outcomes: The Case of the 2016 Election." In The Palgrave Handbook of Political Economy, edited by Ivano Cardinale and Ivano Scazzeri, 333-440. London: Palgrave.

Frank, Jason. 2018. "Pluralism and Praxis." In The Oxford Handbook of Populism, edited by Cristobal Rovira Kaltwasser, Paul A. Taggart, Paulina Ochoa Espejo and Pierre Ostiguy. New York: Oxford University Press.

Frey, Carl Benedikt, Thor Berger, and Chinchih Chen. 2018. "Political Machinery: Did Robots Swing the 2016 U.S. Presidential Election?" Oxford Martin School Working Paper. 
Galston, William. 2018. Anti-Pluralism: The Populist Threat to Liberal Democracy. New Haven: Yale University Press.

Geer, John. 1988. "What Do Open Ended Questions Measure?" Public Opinion Quarterly 52 (3):36571.

Geer, John. 1991. "Do Open-Ended Questions Measure 'Salient' Issues?" Public Opinion Quarterly 55 (3):360-70.

Goodwyn, Lawrence. 1976. Democratic Promise. New York: Oxford University Press.

Green, Joshua. 2017. Devil's Bargain -- Steve Bannon, Donald Trump, and the Storming of the Presidency. New York: Penguin.

Grimmer, Justin, Eitan Hersch, Marc Meredith, Jonathan Mummolo, and Clayton Nall. 2018. "Obstacles to Estimating Voter ID Laws' Effect on Turnout." Journal of Politics 80 (3):1045-1051.

Hochshild, Arle 2016. Strangers in Their Own Land. New York: New Press.

Johnson, Simon, and James Kwak. 2010. 13 Bankers: The Wall Street Takeover and the Next Financial Meltdown. New York: Pantheon.

Judis, John B. 2016. The Populist Explosion: How the Great Recession Transformed American and European Politics. New York: Columbia Global Reports.

Kaltwasser, Cristobal Rovira, Paul A. Taggart, Paulina Ochoa Espejo, Pierre Ostiguy, and Cas Mudde. 2018. "Populism: An Ideational Approach." In The Oxford Handbook of Populism, edited by Cristobal Rovira Kaltwasser, Paul A. Taggart, Paulina Ochoa Espejo, Pierre Ostiguy and Cas Mudde. New York: Oxford University Press.

Kell, Lars Broder, and Sven Felix Kellerhoff. 2018. "Mit zynischem Kalkül drängten die Generäle zum Frieden." Die Welt.

Kelly, Stanley 1983. Interpreting Elections. Princeton: Princeton University Press.

Kinder, Donald, and Lynn M. Sanders. 1996. Racial Politics and Democratic Ideals. Chicago: University of Chicago Press.

Kolb, Eberhard, and Dirk Schumann. 2013. Die Weimarer Republik. 8th ed. Munich: DeGruyter Oldenbourg.

Kranish, Michael, and Marc Fisher. 2016. Trump Revealed. New York: Simon \& Schuster.

Lazonick, William. 2016. The Value Extracting CEO: How Executive Stock-Based Pay Undermines Investment in Productive Capabilities. New York: Institute for New Economic Thinking.

Lazonick, William. 2017. The Functions of the Stock Market and the Fallacies of Shareholder Value. New York: Institute for New Economic Thinking.

Levitsky, Steven, and Daniel Ziblatt. 2018. How Democracies Die. New York: Crown.

Lopez, German. 2017. "The Past Year of Research Has Made It Very Clear: Trump Won Because of Racial Resentment." Vox, December 15, 2017. https://www.vox.com/identities/2017/12/15/16781222/trump-racism-economic-anxietystudy.

Lupia, Arthur. 2018. "How to Improve Coding Coding For Open-Ended Survey Data: Lessons From the ANES." In The Palgrave Handbook of Survey Research, edited by Daniel L. Vannette and Jon A. Krosnick, 121-27. New York: Palgrave Macmillan.

Monnat, Shannon, and David Brown. 2017. "Deaths of Despair and Support For Trump in the 2016 Presidential Election." Journal of Rural Studies 55 (October):227-36.

Mounk, Yascha. 2018. The People vs. Democracy: Why Our Freedom Is in Danger and How to Save It. Cambridge: Harvard University Press.

Müller, Jan-Werner. 2016. What Is Populism? Philadelphia: University of Pennsylania.

Mutz, Diana C. 2017. "Status Threat, Not Economic Hardship, Explains the 2016 Presidential Vote." Proceedings of the National Academy of Science 115 (19):E4330-E4339.

Phillips-Fein, Kim. 2009. Invisible Hands. New York: W.W. Norton.

Popper, Karl. 1963. Conjectures and Refutations. London: Routledge.

Schwartz, Michael. 1976. Radical Protest and Social Structure. New York: Academic Press.

Schweitzer, Peter. 2015. Clinton Cash. New York: HarperCollins.

Shen, Leilei, and Peri Silva. 2018. "Value-Added Exports and U.S. Local Labor Markets: Does China Really Matter." European Economic Journal 101 (January):479-504.

Sides, John. 2016. "Five Key Lessons From Donald Trump's Surprising Victory." Washington Post, November 9, 2017. Accessed November 10, 2017. 
https://www.washingtonpost.com/news/monkey-cage/wp/2016/11/09/five-key-lessonsfrom-donald-trumps-surprising-victory/?utm term=.fd9cf354a5d0 .

Sides, John, Michael Tesler, and Lynn Vavreck. 2018. Identity Crisis: The 2016 Presidential Campaign and the Battle for the Meaning of America. Princeton: Princeton University Press.

Stiglitz, Joseph. 2003. Globalization and Its Discontents. New York: Norton.

Stokes, Donald E., Angus Campbell, and Warren Miller. 1958. "Components of Electoral Decision." American Political Science Reveiw 52 (2):367-87.

Storm, Servaas. 2017. "The New Normal: Demand, Secular Stagnation, and the Vanishing Middle Class." https://www.ineteconomics.org/uploads/papers/WP 55-Storm-The-NewNormal.pdf

Taylor, Lance, and Oslem Omer. 2018. "Race to the Bottom: Low Productivity, Market Power, and Lagging Wages." Institute for New Economic Thinking Working Paper No. 80.

https://www.ineteconomics.org/uploads/papers/Lance-Taylor-Race-to-Bottom.pdf

Temin, Peter. 2015. The American Dual Economy: Race, Globalization, and the Politics of Exclusion. New York: Institute for New Economic Thinking. https://www.ineteconomics.org/research/research-papers/the-vanishing-middle-class-thegrowth-of-a-dual-economy

Temin, Peter. 2016. Race and the Vanishing Middle Class. Cambridge: MIT Press.

Tesler, Michael. 2012. "The Spillover of Racialization into Health Care: How President

Obama Polarized Public Opinion by Race and Racial Attitudes." American Journal of Political Science 56 (3):690-704

Tesler, Michael. 2016. "Views About Race Mattered More in Electing Trump Than In Electing Obama." Washington Post, November 22, 2016. Accessed November 22, 2016.

Tooze, Adam. 2018. Crashed: How a Decade of Financial Crises Changed the World. New York: Viking.

Wattenberg, Martin P. 1998. The Decline of American Political Parties, 1952-1996. Cambridge: Harvard University Press.

Wattenberg, Martin P. 2002. "The Decline of Party Mobilization." In, 64-76. New York: Oxford.

Weil, David 2017. The Fissured Workplace Cambridge: Harvard University Press.

Weyland, Kurt. 1999. "Neoliberal Populism in Latin America and Eastern Europe." Comparative Politics 31 (4):379-401.

Weyland, Kurt. 2001. "Clarifying a Contested Concept: Populism in the Study of Latin American Politics." Comparative Politics 34 (1):1-22.

Winkler, Heinrich August. 1993. Weimar 1918-33 Die Geschichte der ersten deutschen Demokratie. Munich: Verlag C.H. Beck.

Wright, Gerald C. 1993. "Errors in Measuring Vote Choice in the National Election Studies, 1952-88." American Journal of Political Science 37 (1):291=316.

Zonta, Michela, Sarah Edelman, and Colin McArthur. 2016. The Role of Midwestern Housing Instability in the 2016 Election. Washington, D.C.: Center for American Progress. 


\section{Notes}

\footnotetext{
${ }^{1}$ The literature is already enormous, and conclusions about race and gender have in many quarters hardened into a possibly misleading common sense. Among leading scholarly studies, see (Sides, Tesler, and Vavreck 2018); (Tesler 2016); (Mutz 2017); (Sides 2016). Though it predates the emergence of Trump, an important piece that has helped us interpret some of our results on public opinion about the Affordable Care Act is (Tesler 2012). On the common sense reference, see (Lopez 2017).

${ }^{2}$ See: (Rose 2007).

${ }^{3}$ Analysis of Latin America and populism is extensive and methodologically diverse. See: (Weyland 1999), (Weyland 2001); (Dornbusch and Edwards 1992); (Edwards 2012).

${ }^{4}$ Pluralist critiques of populism include (Galston 2018); (Levitsky and Ziblatt 2018); (Mounk 2018); (Judis 2016); and (Müller 2016).

${ }^{5}$ For the distinction between organizational and ideational Populism, see (Kaltwasser et al. 2018).

${ }^{6}$ (Frank 2018); (Goodwyn 1976); (Schwartz 1976).

${ }^{7}$ Among many sources on women's engagement in the Alliance movement, see (Jeffery 1975); on race, see especially Goodwyn 1976).

${ }^{8}$ The literature is gigantic, but see, e.g., (Winkler 1993); (Kolb and Schumann 2013); (Buettner 2008).

${ }^{9}$ See, e.g., (Stiglitz 2003), but especially the "dual economy" literature cited below.

${ }^{10}$ Arendt wrote widely on the consequences of collective detachment from the actions of the state. Her original discussion focused on imperialism, not populism, but she devoted considerable attention to racist ideas also. Our focus in this paper is on her analysis in (Arendt 1973); her discussion of the economics of the period, on the other hand, is not our focus here. That rather clearly needs rethinking and updating. ${ }^{11}$ See, especially, (Temin 2016).

${ }^{12}$ (Winkler 1993); (Kolb and Schumann 2013); see also the striking discussion in (Kell and Kellerhoff 2018).

${ }^{13}$ See the discussion in, e.g., (Popper 1963). An example of how the Goldwater campaign shifted from emphasizing free market economics - which in 1964 did not sell well - to an emphasis on moral decline which proved more popular - is recounted in (Phillips-Fein 2009).

${ }^{14}$ See, e.g., (Kranish and Fisher 2016); (Blair 2015); (Green 2017); and the discussion below of his speeches.

${ }^{15}$ (Temin 2016); (Storm 2017); (Taylor and Omer 2018); (Ferguson, Jorgensen, and Chen 2018a).

${ }^{16}$ (Tooze 2018); (Burnham and Ferguson 2014).

${ }^{17}$ See, e.g., the NBC/Wall Street Journal poll of July, 2016, available on the web at https://www.scribd.com/document/318507755/NBC-Wall-Street-Journal-National-Poll

18 (Green 2017); (Allen and Parnes 2017), among many sources.

19 (Green 2017); (Allen and Parnes 2017).

${ }^{20}$ (Allen and Parnes 2017); (Green 2017); (Kranish and Fisher 2016); (Blair 2015).

${ }^{21}$ (Kranish and Fisher 2016); (Allen and Parnes 2017).

${ }^{22}$ (Green 2017); see the broader discussion of far right media in (Faris et al. 2017);

${ }^{23}$ See, e.g., (Kranish and Fisher 2016).

${ }^{24}$ (Allen and Parnes 2017); (Blair 2015); (Kranish and Fisher 2016); (Green 2017).

${ }^{25}$ For this and the next several paragraphs, see the text of Trump's announcement speech, available at the UCSB American Presidency Project archive, at http://www.presidency.ucsb.edu/ws/index.php?pid=110306

${ }^{26}$ (Green 2017); (Ferguson, Jorgensen, and Chen 2018b).

${ }^{27}$ (Ferguson, Jorgensen, and Chen 2018a).

${ }^{28}$ (Ferguson, Jorgensen, and Chen 2018a).

29 (Allen and Parnes 2017).

${ }^{30}$ (Allen and Parnes 2017); (Ferguson, Jorgensen, and Chen 2018a).
} 
${ }^{31}$ The text of Trump's acceptance speech can be found through the American Presidency Project: http://www.presidency.ucsb.edu/ws/index.php?pid=117935.

${ }^{32}$ (Blake 2016) gives the text of Trump's "best" speech, delivered at Charlotte, NC. Discussion of specific passages in the next few paragraphs comes from there.

${ }^{33}$ See, e.g., (Green 2017).

${ }^{34}$ See the discussion and references in (Ferguson, Jorgensen, and Chen 2018b); (Allen and Parnes 2017); (Green 2017).

${ }^{35}$ The ANES data on primary voting are imperfect because of small n's and the reliance upon respondents' recall in autumn 2016 of their behavior in the previous winter or spring. Some failures of memory and motivated errors undoubtedly occurred. But the respondents reporting Trump primary votes undoubtedly were strong Trump supporters, whether or not they actually voted. They seem well worth analyzing. See also the discussion below on other voting recall problems.

${ }^{36}$ The random intercept (or "mixed model") can be thought of as an estimation of the general equation for each congressional district. That should pick up variation across those and thus be more accurate. But there is a major qualification to this: The question of appropriate weights. Existing software for complex surveys makes it difficult to estimate mixed models. This is particularly the case in national surveys like ANES, which sometimes have relatively few respondents in particular districts. We experimented with various approaches, including various work arounds for spatial spillovers in congressional districts. What was feasible was not perfect and what was closer to perfect was not feasible. In this paper we use level 1 survey weight and there is no level 2 weight since we treat all congressional district the same. We expect to do better in the future. This circumstance makes us very cautious about trumpeting a result in Table 9 that we discuss below, where not only an intercept, but another level 2 variable was significant. See the discussion of voters and non-voters who switched to Trump below.

${ }^{37}$ Cf. (Kinder and Sanders 1996).

${ }_{38}^{38}$ (Sides, Tesler, and Vavreck 2018) (Tesler 2012); (Temin 2015); (Temin 2016).

39 The individual data for this paper come from the American National Election Survey for 2016. Most of the other data, especially for Congressional districts, ultimately derives from the U.S. Census Bureau's various compilations, especially its American Community Survey. But conforming data to changing congressional districts requires care, because they shift over time, making comparisons treacherous. We drew heavily from other datasets, such as that produced by the Social Science Research Council's Measure of America, available on the web at http://www.measureofamerica.org/congressional-districts-2015/ Their data are described as accurate for congressional districts as of April 2015. We also used Policy Map's compilations for the $115^{\text {th }}$ Congress; data on presidential voting by congressional district came from the set constructed by the Daily Kos at https://www.dailykos.com/stories/2013/07/09/1220127/-Daily-KosElections-2012-election-results-by-congressional-and-legislative-districts. We drew on the Daily Kos' compilation of data on religious affiliations at https://www.dailykos.com/stories/2018/1/7/1728838/-TheDaily-Kos-Elections-guide-to-the-nation-s-religious-populations-by-congressional-district Also helpful was a set of economic and social data issued by the Economic Innovation Group of Washington, D.C. We used their 2017 study which drew on data for earlier years. Their recent studies are available here: https://eig.org/dci.

${ }^{40} \mathrm{We}$ are aware that such an exploratory procedure, which we suspect may be pursued by more scholars than care to acknowledge it, renders standard significance tests suspect. It is our hope that an insistence on high estimated significance levels, e.g. $p<.001$, partially mitigates this problem. We also pay close attention to the theoretical coherence of our results.

${ }^{41}$ See, e.g., (Allen and Parnes 2017) on the campaign. The racial resentment and modern sexism coefficients are roughly equivalent to attitudes about the ACA, and at least twice as big as the other coefficients.

${ }^{42}$ (Sides, Tesler, and Vavreck 2018).

${ }^{43}$ (Tesler 2012).

${ }^{44}$ At the same time, we believe that views of the ACA and other social welfare programs - traditionally quite strong factors in choices between Republican and Democratic candidates, though muted by Trump's leftward nods - almost certainly did play some part in November voting decisions in their own right. For the sake of statistical clarity, however, we also performed a regression in which the ACA item was dropped. The pseudo R-squared was nearly as high (0.52 rather than 0.58$)$ and the multicollinearity 
problem receded markedly (a Condition Index of 11.6 instead of 16.3.) Substantively, nothing much changed. The estimated coefficients for three other variables increased somewhat, but not a lot.

${ }^{45}$ If party is a cause of other included variables and works through them to affect voting, the party coefficient will reflect only the direct effects of party loyalty (controlling for the other factors); it will ignore party's indirect effects through other variables. If party is partly a consequence of some or all of the other included factors, a control for such a "post-treatment effect" notoriously leads to underestimates of the impacts of the other factors. Since decades of research have not succeeded in definitively determining to what extent party loyalty is either a cause or a consequence (or both) of issue attitudes, any such "controls" should be used and interpreted with caution.

${ }^{46}$ Contrary to a widespread impression, the candidate questions do not actually mention the word "like" or "dislike." They ask what, if anything might incline someone to vote for or against a candidate.

${ }^{47}$ See, e.g., (Stokes, Campbell, and Miller 1958) (Kelly 1983); (Wattenberg 1998), (Wattenberg 2002);(Geer 1988), (Geer 1991).

${ }^{48}$ See the discussion in (Lupia 2018) and the task force report on the web here: https://electionstudies.org/2008-open-ended-coding-project/

${ }^{49}$ See the report cited in the previous note.

${ }^{50}$ See the references to work by Geer and Wattenberg, above.

${ }^{51}$ See the discussion in (Green 2017); (Ferguson, Jorgensen, and Chen 2018b, Schweitzer 2015).

${ }^{52}$ Thus about $5 \%$ of the complete respondent pool.

${ }^{53}$ (Case and Deaton 2017); (Monnat and Brown 2017); but especially the discussion and other references in (Ferguson, Jorgensen, and Chen 2018b).

${ }^{54}$ The literature is too enormous to inventory. But see, on banks and the bailouts, (Johnson and Kwak 2010); (Ferguson and Johnson 2009a), (Ferguson and Johnson 2009b). More broadly, see the discussion of the midterm elections of 2014 in (Burnham and Ferguson 2014) and the dual economy literature cited above.

55 (Case and Deaton 2017); (Monnat and Brown 2017).

${ }^{56}$ Cf. (Autor et al. 2016), (Autor et al. 2017) on the Clinton vote in 2016, though see also (Shen and Silva 2018). We expect that Autor, et al.'s basic point will prove out. Anyone who thinks that imports did not destroy significant parts of the economies of states like Pennsylvania or Michigan since the late seventies is quite mistaken. But nothing in our paper hangs on any specific account about China. Note the concentration in our regressions on very difficult-to-find long-run rates of economic growth in various congressional districts. (Ferguson, Jorgensen, and Chen 2018b) summarize work on the dual economy by (Temin 2016), (Storm 2017), and (Taylor and Omer 2018). They relate it to other research by (Weil 2017) and (Lazonick 2016) and (Lazonick 2017) and analyze how these developments affected the 2016 election. On automation, see, e.g., (Frey, Berger, and Chen 2018).

57 (Zonta, Edelman, and McArthur 2016) and (Monnat and Brown 2017).

${ }^{58}$ Several types of spatial regression can be useful. In cases like ours, one proceeds empirically, by comparing different types of spatial lag structures. One begins by testing whether spatial autocorrelation exists, using Moran's I test of residuals. Congressional district data is typically spatially autocorrelated (see (Ferguson, Jorgensen, and Chen 2017), and that is what we found in this case. An appropriate response thereafter is to use Lagrange Multiplier tests and AIC tests. We found that so-called Spatial Durbin models gave the best fit. They include spatial lags in the independent variables.

${ }^{59}$ Some analysts who have mechanically assumed a linear effect of education have missed this curvilinearity. Controlling for other factors, only middling education levels are associated with Trump support.

${ }^{60}$ The Johnson Act; see the discussion in (Ferguson, Jorgensen, and Chen 2018b).

${ }^{61}$ The joint inclusion of change in employment and change in the number of business establishments adds some multicollinearity; we report those results, but we prefer the more concise regression.

${ }^{62}$ (Wright 1993).

${ }^{63}$ Predicting the decision among 2012 non-voters to turn out for Trump by using voter validation data instead of self-reported turnout produces slightly different results. Namely, using validated votes suggests that the interaction term between identification as white and an expressed need for a strong leader is unnecessary - the interaction is insignificant, but the two isolated variables produce statistically significant coefficients. All other aspects of this model remain unchanged. When it comes to predicting the decision of 
2012 Obama voters to turn out for Clinton or abstain, the differences from using voter validation are more substantial: attitudes about limiting imports, and perceptions that the economy is good, become insignificant. Model diagnostics reveal a high condition index (18.8), indicating high multicollinearity.

But it is not obvious that standard vote validation methods are superior to the recall data. Latino and Black voters are more likely than Whites to be unlisted or incorrectly listed in voter-matching databases (Grimmer et al. 2018). States also vary widely in their record-keeping on voting behavior, with frequencies of inaccurate and missing data varying across state lines (Berent, Krosnick, and Lupia 2016). ${ }^{64}$ Out of the 4271 ANES respondents (2568 voters), 154 were straight switchers and 187 had come in from the cold. 139 respondents reported voting for Obama in 2012 but not voting in 2016.

${ }^{65}$ That is our interpretation of our evidence that not only the intercept, but the 2013 median income in congressional districts had detectable effects on the switchers' decisions. Our caution about the weights, discussed above in note 36, makes us hesitant to make too much of this result. But it is direct if less than conclusive evidence about the importance of districts that were relatively "left out" of the recovery as stimuli to switching..

${ }^{66}$ See the discussion and references in (Ferguson, Jorgensen, and Chen 2018a).

${ }^{67}$ (Ferguson, Jorgensen, and Chen 2018a).

${ }^{68}$ Note that Sanders primary voters were surely more activist and engaged than the greater ranks of Sanders supporters. An inference that $20 \%$ of all Sanders supporters emulated the primary voters would be fallacious.

${ }^{69}$ See, e.g., (Hochshild 2016). 